\title{
Review on Experimental Treatment Strategies Against Trypanosoma cruzi
}

This article was published in the following Dove Press journal:

Journal of Experimental Pharmacology

\author{
Ana Lia Mazzeti ${ }^{1-3}$ \\ Patricia Capelari-Oliveira' \\ Maria Terezinha Bahia ${ }^{3}$ \\ Vanessa Carla Furtado \\ Mosqueira $\mathbb{D}^{\prime}$ \\ 'Laboratório de Desenvolvimento \\ Galênico e Nanotecnologia, Escola de \\ Farmácia, Universidade Federal de Ouro \\ Preto, Ouro Preto, Minas Gerais, 35400- \\ 000, Brazil; ' 2 Laboratório de Biologia \\ Celular, Instituto Oswaldo Cruz, \\ Fundação Oswaldo Cruz, Rio de Janeiro, \\ Rio de Janeiro, 21040-360, Brazil; \\ ${ }^{3}$ Laboratório de Doenças Parasitárias, \\ Escola de Medicina \& Núcleo de \\ Pesquisas em Ciências Biológicas, \\ Universidade Federal de Ouro Preto, \\ Ouro Preto, Minas Gerais, 35400-000, \\ Brazil
}

Correspondence: Vanessa Carla Furtado Mosqueira

Laboratório de Desenvolvimento Galênico e Nanotecnologia, Escola de Farmácia, Universidade Federal de Ouro Preto, Morro do Cruzeiro, Ouro Preto, MG, 35400-000, Brazil

Tel +55 31 3559- 1032

Email mosqueira@ufop.edu.br
Abstract: Chagas disease is a neglected tropical disease caused by the protozoan Trypanosoma cruzi. Currently, only nitroheterocyclic nifurtimox (NFX) and benznidazole (BNZ) are available for the treatment of Chagas disease, with limitations such as variable efficacy, long treatment regimens and toxicity. Different strategies have been used to discover new active molecules for the treatment of Chagas disease. Target-based and phenotypic screening led to thousands of compounds with anti-T. cruzi activity, notably the nitroheterocyclic compounds, fexinidazole and its metabolites. In addition, drug repurposing, drug combinations, re-dosing regimens and the development of new formulations have been evaluated. The CYP51 antifungal azoles, as posaconazole, ravuconazole and its prodrug fosravuconazole presented promising results in experimental Chagas disease. Drug combinations of nitroheterocyclic and azoles were able to induce cure in murine infection. New treatment schemes using BNZ showed efficacy in the experimental chronic stage, including against dormant forms of $T$. cruzi. And finally, sesquiterpene lactone formulated in nanocarriers displayed outstanding efficacy against different strains of $T$. cruzi, susceptible or resistant to BNZ, the reference drug. These pre-clinical results are encouraging and provide interesting evidence to improve the treatment of patients with Chagas disease.

Keywords: Trypanosoma cruzi, drug discovery, new chemical entities, repurposing, drug combination, nanomedicine

\section{Introduction}

Chagas disease (American trypanosomiasis) was discovered and described by Carlos Chagas in 1909. ${ }^{1}$ The disease is caused by the protozoan Trypanosoma cruzi and affects 6-7 million people worldwide, with an estimated 75 million people at risk of infection. ${ }^{1,2}$ It is a neglected disease and related to poverty in tropical and subtropical countries, especially in Latin America. ${ }^{3}$ The affected population lives in rural and peri-urban areas in inappropriate buildings and in vulnerable socioeconomic conditions. ${ }^{4}$ Recently, Chagas disease has spread to nonendemic areas in Europe, United States and Japan, and it has become a globalized public health and medical problem. ${ }^{3,4}$

T. cruzi infection is transmitted mainly via insect vector, where trypomastigotes of $T$. cruzi in the excreta of contaminated blood-sucking triatomines can penetrate sites of lesioned skin or mucosa in humans. ${ }^{5}$ Other transmission routes have been also reported, such as congenital infection, ${ }^{6,7}$ blood transfusions ${ }^{8}$ or organ transplants, laboratory accidents, ${ }^{9}$ and oral contamination. ${ }^{10,11}$ Sustained efforts to control the vector have resulted in a decrease in the incidence of Chagas disease in several countries of Southern Cone in Latin America. ${ }^{12}$ In recent years, the 
epidemiological relevance of oral transmission has been increased, especially in countries of the Amazon region. ${ }^{13-}$ 15 Several outbreaks associated with orally transmitted acute Chagas disease have been related to the intake of contaminated foods/juices. ${ }^{16}$

The acute phase of Chagas disease persists for 4-8 weeks after infection and it is asymptomatic in most cases. ${ }^{17}$ Some symptoms, such as fever, malaise, lymph nodes and subcutaneous edema, hepatosplenomegaly and electrocardiographic or neurological disorders eventually appear. ${ }^{17}$ The acute severe symptoms, as myocarditis, pericardial effusion, and meningoencephalitis affect $1-5 \%$ of patients, ${ }^{18}$ mainly children and immunosuppressed patients. ${ }^{19-21}$ In the absence of an effective etiologic treatment, the chronic phase gradually sets in. ${ }^{17,18}$ Most of chronic patients are asymptomatic, characterized by the undetermined clinical form of the disease, and may remain so for an indefinite period. In these cases, the patients have detectable anti-T. cruzi antibodies, absence of clinical signs and symptoms of cardiac and digestive clinical forms of the disease. ${ }^{22}$ However, after 10-30 years of asymptomatic period, $30-40 \%$ of chronically infected individuals may progress to symptomatic forms of Chagas disease. ${ }^{17,18}$ About $14-45 \%$ of them develop cardiac abnormalities and dysfunctions (cardiac form), and 10-21\% present intestinal involvement, as megaviscera, specially megaesophagus and megacolon (digestive form). ${ }^{17,18,22,23}$

Clinical manifestations of Chagas disease, specially chronic Chagas cardiomyopathy, are responsible for high morbidity and mortality in economically productive young adults, and result in progressive inability to continue working and consequent burden of the health system. ${ }^{24,25}$ Experimental and clinical studies demonstrate that the presence of the parasites and their DNA in tissues is closely associated with the pathogenesis of the disease which reinforces the hypothesis that the etiological treatment improves patient outcome. ${ }^{26-31}$

In this review, we attempted to provide an overview of the most impressive experimental preclinical results concerning new chemical entities and therapeutic strategies tested in experimental T. cruzi infection. PubMed, Scopus, and Web of Science databases were accessed concerning chemotherapeutic options that have been tested. As a plethora of new chemical compounds have already been tested in vitro, only in vivo data were selected.

\section{Chagas Disease Chemotherapy}

Several new compounds were tested for the treatment of Chagas disease until the 1960s but without promising results. ${ }^{27}$ Afterwards, a more effective class of anti- $T$. cruzi agents were introduced - the nitrofurans, ${ }^{32-34}$ among which nifurtimox (NFX) stood out for its superior efficacy. ${ }^{32}$ In addition, 2-nitroimidazole derivative benznidazole (BNZ) was discovered and included for the treatment of Chagas disease. ${ }^{35}$ NFX and BNZ are nitroheterocyclic class of compounds with the nitro groups linked to furan or imidazole rings, respectively. ${ }^{36}$ Currently, BNZ and NFX are standards of care in clinical chemotherapy of Chagas disease, recommended by $\mathrm{WHO}^{2}$ Their mechanism of action has not yet been fully elucidated, but both act as prodrugs and must be activated by nitro-reductases present in $T$. cruzi to exert their cytotoxic effects. ${ }^{36}$ NFX action on $T$. cruzi involves redox cycling and radical species that results in damage to the parasites, i.e. causing marked reduction on the level of intracellular thiols, with evidence of DNA damage and lipid peroxidation. ${ }^{39}$ Differently, the reduction of BNZ occurs through various free radical intermediates and electrophilic metabolites that alkylate macromolecules such as DNA, lipids, and proteins, as recently reviewed by Patterson and Fairlamb. ${ }^{37}$ There is also the hypothesis that BNZ may act via immune system control producing trypanosome death through interferon- $\gamma$ that is likely to be increased due to inflammation caused by macromolecule damage ${ }^{38}$ Furthermore, it has been shown that the DNA of parasites affected by BNZ could undergo extensive unpacking with overexpression of DNA repair proteins. These findings support the idea that DNA damage could contribute to the mechanism of action of BNZ. ${ }^{39}$

In 2017, BNZ obtained accelerated first treatment approval for the treatment of Chagas disease in children aged 2 to 12 years by the U.S. Food and Drug Administration (FDA) in the United States. ${ }^{40}$ The treatment regimen with NFX or BNZ is long, and many adverse effects can occur and compromise the continuity of the treatment. Common adverse events in NFX treatment include gastrointestinal symptoms (nausea, vomiting and anorexia), symptoms of central nervous system toxicity (insomnia, irritability, and disorientation) and occasionally headache, rash, myalgia, arthralgia, dizziness or vertigo and mood changes. ${ }^{17,18}$ Less commonly, but more severe adverse effects may appear, such as polyneuropathy, paraesthesia and peripheral neuritis. ${ }^{17,18}$ The common adverse effects of BNZ are allergic dermatitis, nausea, vomiting, anorexia, weight loss, insomnia, loss of taste, onycholysis and dose-dependent peripheral sensitive neuropathy may also appear. ${ }^{17,18}$ Rare serious events include neuropathy and depression of bone marrow. ${ }^{17,18}$ Although the treatment of recent stages of 
infection is efficacious using both nitroheterocyclic drugs, their benefits are limited in the chronic phase, with variation of efficacy following geographical locations. ${ }^{18,41-43}$ In addition to the decrease in treatment effectiveness with the time of infection, the drug side effects are more frequent in patients of advanced ages. ${ }^{2}$

In order to search for new treatment alternatives, preclinical studies have been identified promising new candidates in specific pharmacological classes. Particularly, the C14- $\alpha$-demethylase (CYP51) inhibitors were tested in clinical trials, such as posaconazole and fosravuconazole (or E-1224 a prodrug of ravuconazole), but both failed to induce cure and were less effective than the treatment using BNZ. ${ }^{44,45}$

\section{New Drug Candidates for Chagas Disease}

Some pharmacological classes are specially promising to treat Chagas disease: nitroheterocyclic compounds, inhibitors of sterol biosynthesis, cruzipain inhibitors, aromatic amides, trypanothione reductase inhibitors, ruthenium complexes carrying trypanocidal molecules, oxaboroles and nucleoside derivatives. Table 1 summarizes the main data on investigational compounds. In the class of nitroheterocyclic compounds, fexinidazole demonstrated potential against kinetoplastid diseases, and particularly in $T$. cruzi infections. ${ }^{46-48}$ Fexinidazole (Figure 1) was more efficacious than BNZ in murine model, promoted the reduction of parasitemia and induced cure in mice infected by BNZ-resistant strains upon treatment with $300 \mathrm{mg} / \mathrm{kg} /$ day for 20 days. ${ }^{46}$ Similarly, the treatment of infected mice (Y strain) with sulfone and sulfoxide metabolites of fexinidazole induced $100 \%$ cure in acute phase with $100 \mathrm{mg} /$ $\mathrm{kg} / \mathrm{day}$, indicating that these metabolites are more active than BNZ and the parent drug (fexinidazole). ${ }^{49}$ The mechanism of action of these compounds has not yet been elucidated, but indirect evidence indicates that they are also metabolized by $T$. cruzi nitro-reductases. ${ }^{37}$ Other nitroheterocyclic compounds have been extensively investigated for their activity against $T$. cruzi (see Table 1 and Figure 1), ${ }^{50-58}$ although toxicity potential of this class of molecules can limit their use. Thereby, a thorough experimental study on the toxic potential of new compounds must be performed in the drug discovery process.

Another hit class for the treatment of T. cruzi infections includes the inhibitors of sterol biosynthesis pathway (Figure 2), in particular C14- $\alpha$-demethylase (CYP51) inhibitors, used originally as antifungals. In the repurposing strategy, these compounds can block T. cruzi ergosterol biosynthesis, and compromise the parasite survival. For example, treatment with non-azole VNI (Figure 3) led to the cure of animals in acute and chronic phases of infection with Tulahuen strain. ${ }^{59}$ In addition, VNI promoted suppression of parasitemia and protection against mortality, but did not cure murine infections by $\mathrm{Y}$ and Colombian strains. ${ }^{60-62}$ Similarly, the treatment with VFV, a VNI structure-based fluoro-analog, resulted in complete parasitemia suppression and mortality protection. VFV was more potent than VNI (Figure 3) ${ }^{60}$ Moreover, fenarimol (Figure 3), a CYP51 inhibitor, showed a potent anti- $T$. cruzi activity, and two derivatives were able to induce cure in infected mice, with efficacy comparable to posaconazole and superior to BNZ. ${ }^{57,63,64}$ Other classes of ergosterol biosynthesis inhibitors have been found to impact $T$. cruzi infections (Figure 3 and 4). ${ }^{65-67}$

In view of the excellent activities presented by nitroheterocyclic and azole compounds, new nitrotriazolebased compounds were developed as bifunctional compounds against $T$. cruzi, acting on CYP51 enzyme and acting as substrates of nitroreductases. Nitro-triazoles displayed in vitro anti-T. cruzi activity and induced the reduction of parasitemia in acute model of infection. ${ }^{68-76}$

An important drug target for Chagas disease treatment is cruzipain (also named cruzain), an essential cysteine protease of $T$. cruzi responsible for the proteolytic activity in all stages of parasite life ${ }^{77}$. K777, a vinyl sulfone cruzipain inhibitor, exhibited anti- $T$. cruzi activity and induced the cure in experimental murine models (Figure 3). ${ }^{77,78}$ In infected dogs, the treatment with K777 reduced the myocardial damage caused by the parasite, though it was not able to induce the parasitological cure. ${ }^{79}$ In addition, Cz007 and Cz008 cruzipain inhibitors presented potent activity in vitro, reduced parasitemia, and show cure in $T$. cruzi-infected mice in acute phase. ${ }^{80}$ Nonpeptidic tetrafluorophenoxymethyl ketone reduced parasitemia of infected mice with no apparent toxicity. ${ }^{81}$ Thiazole compounds showed in vitro activity and promoted reduction of parasitemia and mortality possibly by acting as cruzipain inhibitors (Figure 3). ${ }^{82-85}$

Amidine-containing compounds represent a versatile class of drugs, with potential antiprotozoal treatment, acting through multiple mechanisms against $T$. cruzi. ${ }^{86}$ Many compounds presented in vitro and in vivo activity against $T$. cruzi (see Table 1). For example, treatment with DB766 reduced parasite load in blood and heart, and prevented mortality of infected 
Table I Classes of Promising New Chemical Entities for Experimental Treatment of Chagas Disease

\begin{tabular}{|c|c|c|c|}
\hline $\begin{array}{l}\text { Mechanism/ } \\
\text { Target }\end{array}$ & Chemical Class/Compound & Outcome & Ref. \\
\hline \multirow{5}{*}{$\begin{array}{l}\text { DNA and } \\
\text { kinetoplast-DNA } \\
\text { targeting } \\
\text { and } \\
\text { topoisomerase } \\
\text { inhibitors } \\
\text { and } \\
\text { unknow targets }\end{array}$} & Amide-containing thiazoles & Safe compounds that had in vitro and in vivo anti-T. cruzi activities. & [93] \\
\hline & Arylimidamide derivatives & $\begin{array}{l}\text { I8SAB075 exhibited best selective index; and slightly reduced parasitemia } \\
\text { and mortality in mice infection. }\end{array}$ & [92] \\
\hline & $\begin{array}{l}\text { Amidines and analogues } \\
\text { Bis-arylimidamides }\end{array}$ & $\begin{array}{l}\text { Bis-arylimidamides displayed in vitro activity. } 28 \mathrm{SMB} 032 \text { reduced } \\
\text { parasitemia, but without mortality protection. DBI957, DBI959 and } \\
\text { DBI890B reduced parasitemia levels and/or mortality. }\end{array}$ & {$[91,94]$} \\
\hline & $\mathrm{DBI} 83 \mathrm{I}$ and its mesylate salt derivative (DB|965) & $\begin{array}{l}\text { Compounds presented in vitro and in vivo activity. DBI } 965 \text { produced no } \\
\text { parasitological cure, but reduced parasite burden and protected against } \\
\text { mortality }\end{array}$ & [90] \\
\hline & DB766 and analogues & $\begin{array}{l}\text { DB766 displayed potent in vitro activity. In murine infection, the drug } \\
\text { reduced parasite load in blood and heart; reduced hepatic and cardiac } \\
\text { lesions; prevented electrocardiographic alterations and prevented } \\
\text { mortality. }\end{array}$ & [87-89] \\
\hline $\begin{array}{l}\text { Antimicrobial } \\
\text { peptides }\end{array}$ & AS-48 Bacteriocin & $\begin{array}{l}\text { AS- } 48 \text { was active in vitro and in acute stage of mice infection it reduced } \\
\text { parasitemia and in chronic stage the parasitic load. }\end{array}$ & {$[98,99]$} \\
\hline Copper complexes & Ternary copper (II) complexes & Compounds with higher selectivity index were able to reduce parasitemia. & {$[100]$} \\
\hline \multirow[t]{3}{*}{$\begin{array}{l}\text { Cysteine protease } \\
\text { inhibitors } \\
\text { and } \\
\text { Cruzipain inhibitors }\end{array}$} & Fluoromethyl ketone-derivatized pseudopeptides & $\begin{array}{l}\text { K777 is an irreversible peptidyl inhibitor of cruzipain and it was able to } \\
\text { reduce parasitemia and mortality, and induce cure in murine model. In } \\
\text { infected dogs, it reduced cardiac damage, but without cure. } \\
\text { Nonpeptidic tetrafluorophenoxymethyl ketone reduce parasitemia in } \\
\text { acutely infected mice with no apparent toxicity. }\end{array}$ & {$[81]$} \\
\hline & $\begin{array}{l}\text { Reversible cruzipain inhibitors containing a nitrile } \\
\text { "warhead" }\end{array}$ & $\begin{array}{l}\text { Cz007 and Cz008 presented potent in vitro activity and displayed } \\
\text { parasitemia reduction and cure in mice acutely infected. }\end{array}$ & [80] \\
\hline & Thiazole compounds & $\begin{array}{l}\text { Thiazole compounds showed in vitro activity and promoted reduction of } \\
\text { parasitemia and mortality in infected mice. These compounds inhibited } \\
\text { cruzipain. }\end{array}$ & [82-85] \\
\hline \multirow{7}{*}{$\begin{array}{l}\text { Ergosterol } \\
\text { biosynthesis } \\
\text { inhibitors }\end{array}$} & 4-aminopyridyl-based lead compounds & $\begin{array}{l}\text { Compounds showed anti-T. cruzi effects in acute and chronically infected } \\
\text { mice, but without cure. }\end{array}$ & [67] \\
\hline & Fenarimol analogues & $\begin{array}{l}\text { Fenarimol analogues were active in vitro and in vivo against } T \text {. cruzi infected } \\
\text { mice }\end{array}$ & {$[57,63,64]$} \\
\hline & Non-azole LP-I0 & LP-I0 was able to reduce parasitemia and to induce cure in infected mice. & [65] \\
\hline & Ravuconazole and EI 224 (fosravuconazole) & $\begin{array}{l}\text { Ravuconazole presented effective control of infection in mice and dogs. } \\
\text { EI } 224 \text { or fosravuconazole, a prodrug of ravuconazole were well tolerated } \\
\text { and effective in suppressing parasitemia. Cure was detected in mice } \\
\text { infected by Y strain, but no cure was observed in Colombian infection in } \\
\text { mice. }\end{array}$ & $\begin{array}{l}{[116,117]} \\
{[118]}\end{array}$ \\
\hline & VFV & $\begin{array}{l}\text { VFV was more potent than VNI in reducing parasitemia and presented } \\
\text { effects on mortality protection. }\end{array}$ & {$[60,119]$} \\
\hline & VNI & $\begin{array}{l}\text { VNI presented promising anti-T. cruzi activity in vitro and in vivo. The drug } \\
\text { promoted reduction of parasitemia in mice infected by different strains. } \\
\text { Cure was detected in animals acute and chronically infected by Tulahuen } \\
\text { strain. }\end{array}$ & {$[59-62]$} \\
\hline & VT-II6I & $\begin{array}{l}\text { VT-II6I is a potent } T \text {. cruzi CYP5I inhibitor and revealed in vitro and in } \\
\text { vivo activity, as well as suppression of parasitemia peak in mice infection by } \\
\text { Y strain. }\end{array}$ & [66] \\
\hline
\end{tabular}


Table I (Continued).

\begin{tabular}{|c|c|c|c|}
\hline $\begin{array}{l}\text { Mechanism/ } \\
\text { Target }\end{array}$ & Chemical Class/Compound & Outcome & Ref. \\
\hline \multirow[t]{7}{*}{$\begin{array}{l}\text { Nitro-heterocyclic } \\
\text { compounds } \\
\text { and } \\
\text { ROS inducers }\end{array}$} & 5-Nitroindazole derivatives & $\begin{array}{l}\text { Megazol, a nitroimidazole-thiadiazole derivative, demonstrated a curative } \\
\text { action in infected mice. The mechanism of action is related to the } \\
\text { impairment of protein synthesis. } \\
\text { Megazol derivatives showed in vitro activity. In infected mice, S2 led to } \\
\text { parasitemia reduction, and S3 to mortality reduction. }\end{array}$ & [54] \\
\hline & Nitrotriazoles & $\begin{array}{l}\text { Nitrotriazole-based compounds exhibited in vitro and in vivo anti-T.cruzi } \\
\text { activity. Some compounds are potential inhibitors of T. cruzi CYP5I and } \\
\text { substrates for the type I nitroreductase. } \\
\text { Triazole-based analogues of BNZ showed in vitro activity. In infected mice, } \\
\text { the analogues exhibited lower potency and higher toxic than BNZ. }\end{array}$ & $\begin{array}{l}{[68-76]} \\
{[58]}\end{array}$ \\
\hline & Fexinidazole & $\begin{array}{l}\text { Fexinidazole was more effective than BNZ, with cure rate greater than } 70 \% \\
\text { in animals infected by different strains and treated during the acute or } \\
\text { chronic phases. }\end{array}$ & [46-48] \\
\hline & Fexinidazole metabolites & $\begin{array}{l}\text { Fexinidazole sulfone and fexinidazole sulfoxide induced higher cure rates } \\
\text { than fexinidazole. }\end{array}$ & {$[47,49]$} \\
\hline & Imidazole Derivatives & $\begin{array}{l}\text { Phthalazine derivatives containing imidazole rings showed in vitro and in } \\
\text { vivo anti-T. cruzi activity. }\end{array}$ & [55] \\
\hline & MK-436 (2,5-nitroimidazole) & $\begin{array}{l}\text { MK- } 436 \text { was highly efficacious against acute and chronic infection by } \\
\text { different strains, and induced cure in acute stage. }\end{array}$ & {$[51,52]$} \\
\hline & Ruthenium complexes & $\begin{array}{l}\text { The ruthenium compounds exhibited potent in vitro and in vivo } \\
\text { trypanocidal activities by acting on active cysteine (cys } \mid 66 \text { ) site or releasing } \\
\text { nitric oxide. NO donor compound led to parasitological cure. }\end{array}$ & {$[101-104]$} \\
\hline \multirow[t]{2}{*}{$\begin{array}{l}\text { Purine Salvage } \\
\text { Pathway }\end{array}$} & Nucleoside derivatives & $\begin{array}{l}\text { Nucleoside analogues presented in vitro activity and the most potent } \\
\text { showed suppression of parasitemia and mortality in acutely infected mice. }\end{array}$ & {$[106,107]$} \\
\hline & Xanthine analogs & $\begin{array}{l}\text { Xanthine analogs showed in vitro activity and were able to reduce } \\
\text { parasitemia in CL-infected mice. }\end{array}$ & {$[105]$} \\
\hline Oxamates & $\begin{array}{l}\text { Benzyl ester of } \mathrm{N} \text {-propyl oxamate; ethyl esters of } \\
\mathrm{N} \text {-propyl and } \mathrm{N} \text {-isopropyl oxamates; and } \\
\mathrm{N} \text {-isopropyl oxamate }\end{array}$ & $\begin{array}{l}\text { Compounds exhibited trypanocidal activity in vitro and in vivo. They acted } \\
\text { as possible inhibitors of T. cruzi } \alpha \text {-hydroxy acid dehydrogenase (HADH)- } \\
\text { isozyme II }\end{array}$ & {$[108-110]$} \\
\hline $\begin{array}{l}\text { Oxaboroles } \\
\text { multiple cellular } \\
\text { targets }\end{array}$ & Oxaboroles & $\begin{array}{l}\text { AN4169 showed broad efficacy in vitro against strains of } T \text {. cruzi and was a } \\
\text { fast-acting trypanocidal. The drug induced cure in mouse model. }\end{array}$ & {$[56,57]$} \\
\hline $\begin{array}{l}\text { Proteasome } \\
\text { inhibitor }\end{array}$ & Triazolopyrimidine & GNF6702 cure mice in chronic phase of infection with $T$. cruzi. & {$[114,115]$} \\
\hline Quinolines & Quinolines & $\begin{array}{l}\text { Tested quinolines were more active in vitro than BNZ. DB2 } 186 \text { reached } \\
70 \% \text { reduction of the parasitemia load in mice infected by } Y \text { strain. }\end{array}$ & {$[111]$} \\
\hline $\begin{array}{l}\text { Sphingosine kinase } \\
\text { inhibitor }\end{array}$ & N,N-dimethylsphingosine (DMS) & $\begin{array}{l}\text { DMS blocked sphingosine-I-phosphate production, a cell mediator during } \\
\text { inflammatory responses, and exhibited anti-parasitic activity in vitro and in } \\
\text { vivo and immunomodulatory actions in chronically infected mice. }\end{array}$ & {$[112]$} \\
\hline Squaramides & Squaramides & $\begin{array}{l}\text { New long-chain squaramides displayed in vitro and in vivo activity with low } \\
\text { toxicity }\end{array}$ & {$[55,113]$} \\
\hline $\begin{array}{l}\text { Terpene and } \\
\text { terpenoid } \\
\text { derivatives }\end{array}$ & Terpenoid derivates & $\begin{array}{l}\text { Synthesized terpenoid derivates displayed in vitro anti-T. cruzi activity and } \\
\text { nontoxic effects upon host cells. In infected mice, these derivatives reduced } \\
\text { parasitic load and anti-T. cruzi antibodies during chronic stage. }\end{array}$ & [55] \\
\hline
\end{tabular}


Table I (Continued).

\begin{tabular}{|c|c|c|c|}
\hline $\begin{array}{l}\text { Mechanism/ } \\
\text { Target }\end{array}$ & Chemical Class/Compound & Outcome & Ref. \\
\hline \multirow{2}{*}{$\begin{array}{l}\text { Polyamine surface } \\
\text { transporters and } \\
\text { metabolism } \\
\text { Trypanothione } \\
\text { metabolism } \\
\text { inhibitors }\end{array}$} & Thiazolidines & $\begin{array}{l}\text { LPSF SF29 displayed trypomastigote lysis and amastigote death, probably by } \\
\text { interfering with polyamine biosynthesis and consequently trypanothione } \\
\text { biosynthesis, leading to increased sensitivity to oxidative metabolism. }\end{array}$ & [96] \\
\hline & Tetradentated polyamine complexes & $\begin{array}{l}\text { Tetraamines presented anti-T. cruzi activity in vitro and in vivo with low } \\
\text { toxicity. }\end{array}$ & [97] \\
\hline
\end{tabular}

Abbreviations: BNZ, benznidazole; NO, nitric oxide; ROS, reactive oxygen species.

mice; the drug reduced hepatic and cardiac lesions and prevented electrocardiographic abnormalities induced by the parasite infection. ${ }^{87-89}$ In addition, DB766 was found in DNAenriched compartments and induced considerable damage to the mitochondria. ${ }^{88}$ Amide-containing thiazole derivatives, arylimidamide derivatives, and other amidines have been found to be active in vitro and in vivo. ${ }^{90-94}$
Trypanosomatids, unlike humans, have a unique redox metabolism based on thiol and relying on trypanothione reductase. This trypanothione enzyme acts in defense against oxidative damage, redox homeostasis and replication, significantly supporting infectivity and survival of the parasite in the host system..$^{95}$ The inhibition of trypanothione reductase metabolism increases the parasite susceptibility to drugs and/or oxidative<smiles>CCCCCCCCCCCC(=O)OCc1ccccc1</smiles><smiles>NC(=O)Cn1ccnc1[N+](=O)[O-]</smiles><smiles>Cn1c([N+](=O)[O-])cnc1-c1nnc(N)s1</smiles><smiles>Cn1c([N+](=O)[O-])cnc1C1=NOC2CCCCC12</smiles><smiles>C=C/C=N\N1CCS(=O)(=O)CC1C</smiles>

\section{Nifurtimox}<smiles>O=[N+]([O-])c1ccco1</smiles><smiles>CCCCCCCC</smiles><smiles>C=C(C)OCc1ncc([N+](=O)[O-])n1C</smiles><smiles>Cc1ccccc1</smiles>
Megazol

Fexinidazole MK-436 $\gamma$

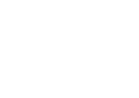<smiles>COC(C)(C)OCCOc1ccc(S(C)(=O)=O)cc1</smiles>

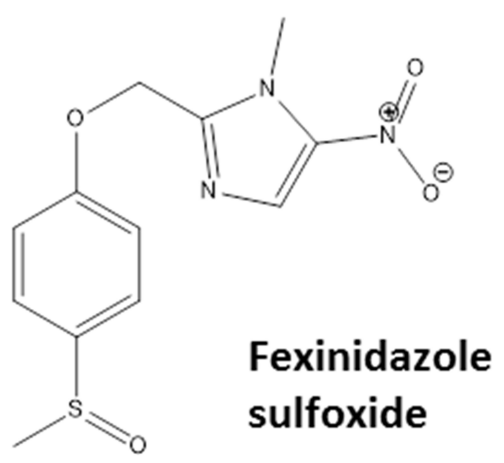

Figure I Chemical structures of the most promising nitro-heterocyclic compounds that induce cure with parasite elimination in mice. 


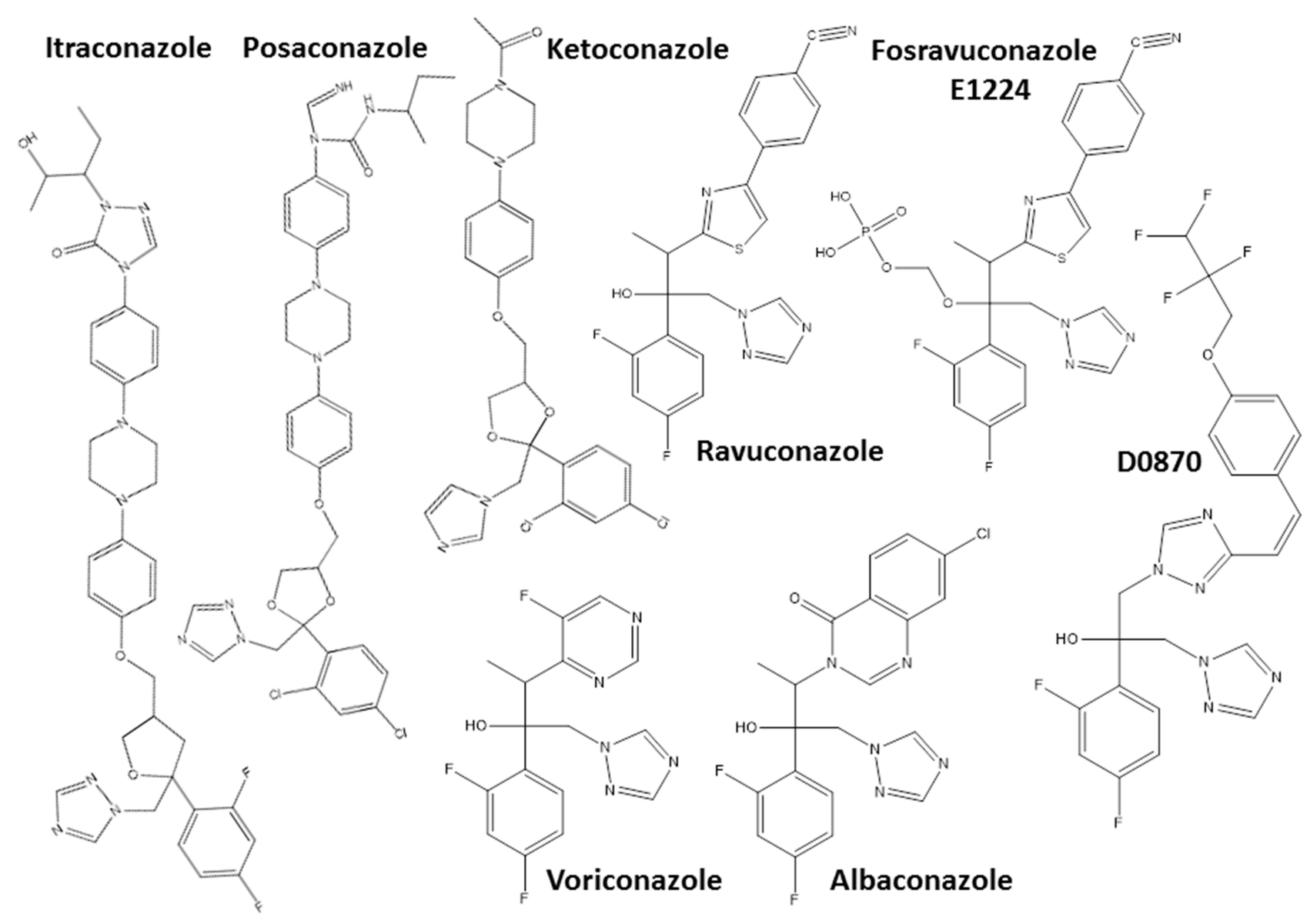

Figure 2 Chemical structures of the most promising azole derivatives that induced cure with parasite elimination in mice.

stress induced by host defense. ${ }^{95}$ Thiazolidines LPSF and SF29 promoted trypomastigote lysis and amastigote death, probably by interfering with polyamine biosynthesis and consequently trypanothione biosynthesis, leading to increased sensitivity of the parasite to the oxidative metabolism. ${ }^{96}$ In addition, tetraamines were able to inhibit iron superoxide dismutase and trypanothione reductase of $T$. cruzi and presented activity in vitro and in vivo with low toxicity. ${ }^{97}$

Other classes as antimicrobial peptides; ${ }^{98,99}$ copper $^{100}$ or ruthenium ${ }^{101-104}$ complexes, compounds that impact on purine salvage pathway, ${ }^{105-107}$ oxaboroles, ${ }^{56,57}$ oxamates, ${ }^{108-110}$ quinolines, ${ }^{111}$ sphingosine kinase inhibitor, ${ }^{112}$ squaramides, ${ }^{55,113}$ terpene and terpenoid derivatives $^{55}$ and proteasome inhibitors, ${ }^{114,115}$ revealed interesting results, impacting the evolution of $T$. cruzi infection (Table 1), but the mechanisms are not well known. Figure 4 shows schematic representation of the main drug targets identified in $T$. cruzi.

\section{Natural Products}

In the search for new alternatives for the therapy of Chagas disease, natural diversity can provide a wide range of bioactive agents or lead compounds. Natural products are the source for structural chemical backbone that could be used to inspire synthesis of new active molecules. Natural products isolated from different botanical sources exhibited activity against $T$. cruzi (see Table 2). ${ }^{120-132}$ Several approaches have been developed focusing on identification and isolation of plantbased products with anti-T. cruzi activity ${ }^{133,134}$ (Table 2). In this sense, extracts from different plants as Salvia, Valeriana, Hypericum, Silybum, Arnica, and Curcuma showed activity against $T$. cruzi. ${ }^{135}$ Sesquiterpene lactones have been demonstrating outstanding anti-T. cruzi activity. ${ }^{136-145}$ They are isolated from a variety of species, mainly from the Asteraceae family. Lychnopholide ${ }^{144}$ and goyazenzolide ${ }^{145}$ are examples of potent sesquiterpene lactones, which showed high efficacy in $T$. cruzi-infected mice. Unfortunately, preclinical research 


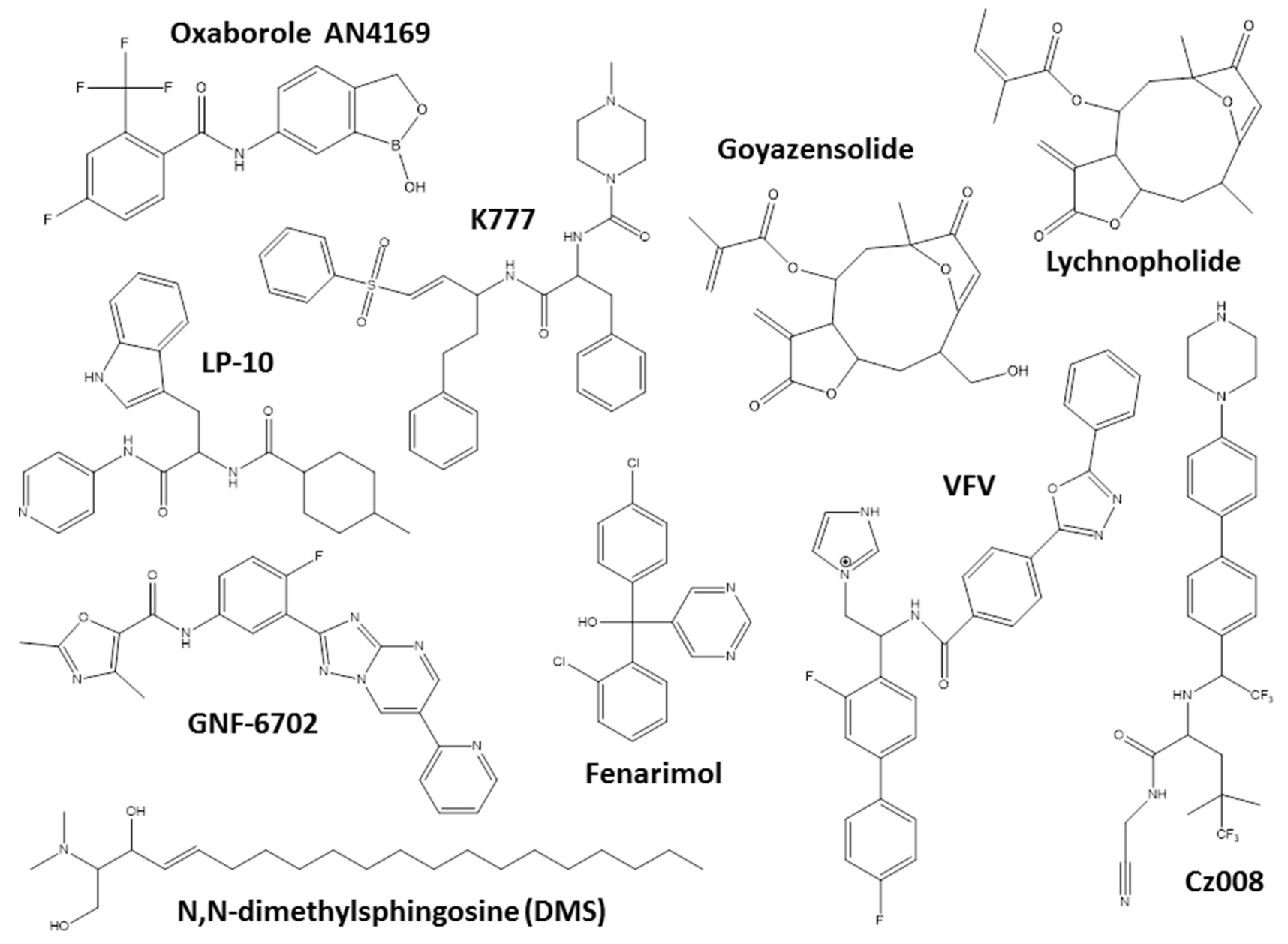

Figure 3 Chemical structures of the miscellaneous classes of most promising compounds with different mechanisms of action that induced cure with parasite elimination in mice.

involving natural products faces obstacles to translate their findings to clinical phases due to difficulties in isolating the active compound and dimensioning the batches, as well as difficulties in the standardization of the plant extracts following the different seasons. ${ }^{134}$

\section{Drug Repurposing}

Drug repurposing is a source of alternative chemotherapies for several diseases, especially those neglected, since the time and cost of the process required for clinical approval can be shortened. Anti-T. cruzi activity of compounds from different pharmacological classes has been tested in experimental infection models (Table 3). Particularly, the antifungals albaconazole, itraconazole, ketoconazole, posaconazole, ravuconazole and its prodrug fosravuconazole, which are CYP51 inhibitors, have demonstrated anti- $T$. cruzi activity by inhibiting ergosterol biosynthesis of the parasite. ${ }^{116-118,146-157}$ The effectiveness of this class of compounds has been demonstrated in several experimental models, and high cure rates has been detected in mice or dog infections. ${ }^{116-118,146,147,151,153}$ In addition, the anticancer drug tipifarnib can also inhibit CYP51 and showed potent suppressive activity on parasitemia in infected mice. ${ }^{158-160}$

The antihypertensive benidipine and antibiotic clofazimine reduced parasite load and inflammatory process in cardiac and skeletal muscle of chronically infected mice. ${ }^{161,162}$ The likely mechanism of action of both compounds would be the inhibition of cruzipain ${ }^{161,162}$ or disruption of calcium homeostasis for benidipine. ${ }^{163,164}$ Differently, the anti-cancer imatinib was moderately active against different strains and forms of $T$. cruzi. ${ }^{165}$ Antidepressants sertraline and fluoxetine showed in vitro anti-T. cruzi activity, while fluoxetine treatment displayed insufficient parasitemia reduction in infected mice. ${ }^{166,167}$ Antihyperuricemic allopurinol was evaluated for Chagas disease treatment and showed controversial results. This drug is a hypoxanthine analogue and acts as an alternative substrate of 


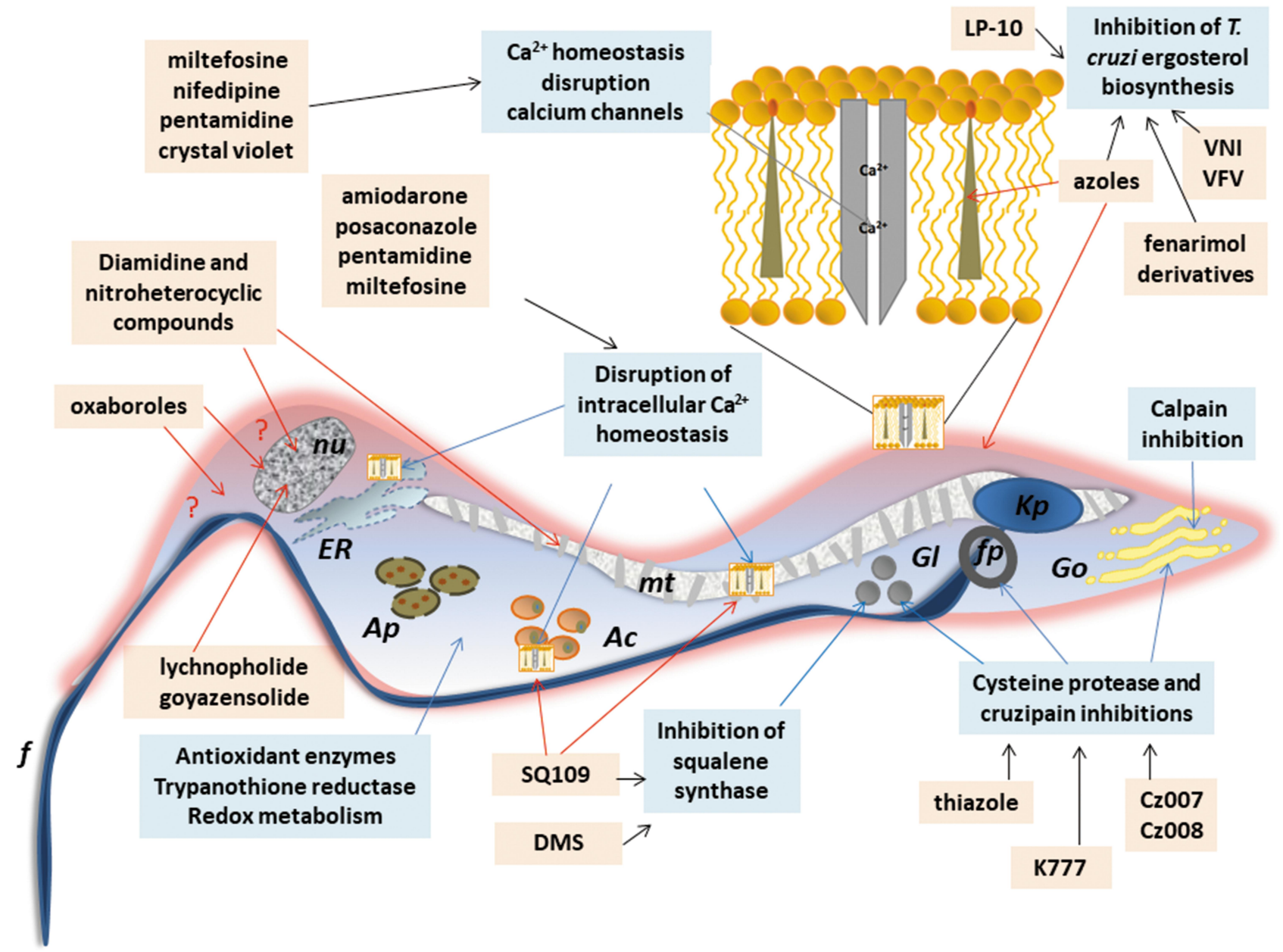

Figure 4 Schematic representation of a trypomastigote of Trypanosome cruzi and the main cellular targets of the investigational compounds in the pre-clinical phase of development.

Notes: The selected targets are in blue boxes and compounds are in rose boxes. Organelles: Kp: kinetoplast, f: flagellum, fp: flagellar pocket, mt: mitochondrion, nu: nucleus, ER: endoplasmic reticulum, Go: golgi apparatus, Ac: acidocalcisomes, Gl: glycosomes, Ap: autophagosomes. The drawing is based on data from Benaim et al and VannierSantos et al. ${ }^{163,228}$

the T. cruzi hypoxanthine-guanine phosphoribosyl transferase. ${ }^{168}$ The enzyme can incorporate allopurinol into parasite RNA, creating a nonfunctional nucleotide, blocking de novo synthesis of purines, affecting protein synthesis, and inducing parasite death. ${ }^{168}$ Studies have been demonstrated the beneficial results of allopurinol treatment in reducing parasitemia and/or modifying the evolution of acute and chronic murine infection. ${ }^{169-171}$ Differently, Mazzeti et al demonstrated that this drug did not affect the evolution of $\mathrm{Y}$ acute infection in mice. ${ }^{172}$

Other drug tested using repositioning strategy are the antiarrhythmic amiodarone, ${ }^{154}$ auranofin ${ }^{173}$ and clomipramine, ${ }^{174,175}$ which were also active against $T$. cruzi in preclinical experimental infections (see Table 3). Amiodarone and miltefosine have mechanisms of action related to disruption of calcium homeostasis in T. cruzi. ${ }^{163}$
Taken together, the preclinical results of drug repositioning strategy indicate that most of them were active but failed to induce sterile cure in mice.

\section{Drug Combination Therapy}

Drug associations concomitantly or sequentially can improve the effectiveness of Chagas disease treatment as well as interfere in the duration of treatment and/or drug dose. Combination therapy using distinct pharmacological classes has been evaluated in experimental T. cruzi infection (Table 4). The use of suboptimal doses or treatment length of BNZ in association with CYP51 inhibitors may maintain or increase the effectiveness of treatment by the synergistic or additive effect of compounds with different mechanisms of action or cellular targets. ${ }^{56,118,119,150,155-157,176-180}$ Similarly, allopurinol combined with low dose of BNZ had a positive interaction 
Table 2 Promising Natural Products in Experimental Treatment of Trypanosoma cruzi Infections

\begin{tabular}{|c|c|c|c|}
\hline Plant & Natural Product & Outcome & References \\
\hline $\begin{array}{l}\text { Aristeguietia } \\
\text { glutinosa }\end{array}$ & $\begin{array}{l}\text { Secondary metabolites isolated from the } \\
\text { hydro-ethanolic extract of the aerial } \\
\text { parts }\end{array}$ & $\begin{array}{l}\text { The substances displayed low in vitro toxicity and anti- T. cruzi effect in } \\
\text { infected mice by inhibiting parasite mitochondrial dehydrogenases and } \\
\text { biosynthesis of membrane sterols. }\end{array}$ & {$[128]$} \\
\hline $\begin{array}{l}\text { Arrabidaea } \\
\text { brachypoda }\end{array}$ & Dimeric flavonoids from roots & Flavonoids were active against $T$. cruzi in vitro and in infected mice. & {$[129]$} \\
\hline $\begin{array}{l}\text { Carica } \\
\text { papaya }\end{array}$ & Crude seed extracts & $\begin{array}{l}\text { Extracts were able to reduce parasitemia, but not the cardiac } \\
\text { amastigotes nests of infected mice. }\end{array}$ & {$[127]$} \\
\hline $\begin{array}{l}\text { Delphinium } \\
\text { staphisagria }\end{array}$ & Flavonoids from aerial parts & Flavonoids were active against T. cruzi in vitro and in infected mice. & {$[124]$} \\
\hline $\begin{array}{l}\text { Artemisia } \\
\text { annua }\end{array}$ & artemisinin (sesquiterpene lactone) & $\begin{array}{l}\text { Artemisinin presented in vitro activity and inhibited calcium-dependent } \\
\text { ATPase activity in } T \text {. cruzi membranes. }\end{array}$ & {$[136]$} \\
\hline $\begin{array}{l}\text { Lychnophora } \\
\text { passerina }\end{array}$ & $\begin{array}{l}\text { goyazensolide (Sesquiterpene lactone } \\
\text { from the aerial parts) }\end{array}$ & $\begin{array}{l}\text { Goyazensolide was active in vitro and led to parasitemia reduction and } \\
\text { negativation in parasitological tests in mice infection by } Y \text { and } C L \\
\text { strains. }\end{array}$ & {$[145]$} \\
\hline $\begin{array}{l}\text { Lychnophora } \\
\text { trichocarpha }\end{array}$ & $\begin{array}{l}\text { Lychnopholide (LYC) and } \\
\text { LYC-loaded nanocapsules } \\
\text { (sesquiterpene lactone) }\end{array}$ & $\begin{array}{l}\text { Nanocapsules containing lychnopholide reduced parasitemia and } \\
\text { mortality in murine infection and induced cure in mice infected with } T \text {. } \\
\text { cruzi strains resistant and sensitive to BNZ in acute and chronic phases } \\
\text { of infection. LYC-nanocapsules formulation prevented cardiotoxicity in } \\
\text { long term treatment. }\end{array}$ & $\begin{array}{l}{[138-140]} \\
{[144]}\end{array}$ \\
\hline $\begin{array}{l}\text { Mikania } \\
\text { species }\end{array}$ & $\begin{array}{l}\text { Deoxymikanolide and other } \\
\text { sesquiterpene lactones }\end{array}$ & $\begin{array}{l}\text { Deoxymikanolide showed the highest selectivity index and induced } \\
\text { parasitemia and mortality reduction in infected mice. }\end{array}$ & {$[|4|]$} \\
\hline $\begin{array}{l}\text { Tithonia } \\
\text { diversifolia }\end{array}$ & $\begin{array}{l}\text { Tagitinin } \mathrm{C} \text { a sesquiterpene lactone } \\
\text { isolated from leaves }\end{array}$ & $\begin{array}{l}\text { Tagitinin } C \text { presented in vitro and in vivo activity alone and combined } \\
\text { with BNZ. }\end{array}$ & {$[143]$} \\
\hline $\begin{array}{l}\text { Physalis } \\
\text { angulata }\end{array}$ & $\begin{array}{l}\text { Physalins (secosteroids) and } \\
\text { concentrated ethanolic extract }\end{array}$ & $\begin{array}{l}\text { Physalins reduced the invasion process in vitro, and intracellular } \\
\text { parasite load, alone or in combination with BNZ. Concentrated } \\
\text { ethanolic extract showed in vitro and in vivo activity alone and } \\
\text { associated with BNZ. }\end{array}$ & {$[126,130]$} \\
\hline $\begin{array}{l}\text { Piper } \\
\text { jericoense }\end{array}$ & Furofuran lignan & $\begin{array}{l}\text { Furofuran lignan was active in vitro and reduced parasitemia levels in } \\
\text { infected mice. The compound affected the parasite structure without } \\
\text { altering the energetic metabolism. }\end{array}$ & {$[132]$} \\
\hline Salvia gilliesii & Isolated diterpene & $\begin{array}{l}\text { Compound reduced parasite load and increased survival of infected } \\
\text { mice. }\end{array}$ & {$[|3|]$} \\
\hline Senna villosa & $\begin{array}{l}\text { (8-hydroxymethylen)-trieicosanyl } \\
\text { acetate }\end{array}$ & Isolated compound showed in vitro and in vivo activity against $T$. cruzi. & {$[122,125]$} \\
\hline $\begin{array}{l}\text { Zanthoxylum } \\
\text { chiloperone }\end{array}$ & $\begin{array}{l}\text { Canthin-6-one alkaloids and leaves } \\
\text { extract }\end{array}$ & $\begin{array}{l}\text { Canthin-6-one alkaloids exhibited trypanocidal activity in vitro and in } \\
\text { mouse model of acute or chronic infection. Leaves extract reduced } \\
\text { parasitaemia in vivo. }\end{array}$ & {$[121,123]$} \\
\hline $\begin{array}{l}\text { Zanthoxylum } \\
\text { naranjillo }\end{array}$ & Lignans isolated from the leaves & Lignans displayed in vitro and in vivo activities. & {$[120]$} \\
\hline
\end{tabular}

Abbreviation: BNZ, benznidazole. 
Table 3 Drugs Repositioned in Experimental Treatment of Chagas Disease

\begin{tabular}{|c|c|c|c|}
\hline Compound & Original Use & Outcome & References \\
\hline Albaconazole & Antifungal & $\begin{array}{l}\text { Albaconazole suppressed the parasite proliferation, prevented the death of } \\
\text { infected dogs, and induced cure in animals infected by Y strain, but not in those } \\
\text { infected by Berenice- } 78 \text {. }\end{array}$ & [153] \\
\hline Allopurinol & Antihyperuricemic & $\begin{array}{l}\text { Allopurinol was effective in reducing parasitemia and/or modifying the } \\
\text { evolution of acute and chronic murine infection. } \\
\text { Allopurinol derivatives displayed similar in vitro activity than pattern drug and } \\
\text { good bioavailability properties for oral absorption. }\end{array}$ & $\begin{array}{l}{[169,170]} \\
{[171]}\end{array}$ \\
\hline Amiodarone & Antiarrhythmic & $\begin{array}{l}\text { Amiodarone showed in vitro activity against epimastigote and amastigote. In } \\
\text { acute treatment of infected mice, it reduced parasitemia and increased survival. }\end{array}$ & [154] \\
\hline Auranofin & Antirheumatic & $\begin{array}{l}\text { Auranofin showed activity against } T \text {. cruzi in vitro and reduced parasitemia and } \\
\text { mortality in infected mice. }\end{array}$ & [173] \\
\hline Benidipine & Antihypertensive & $\begin{array}{l}\text { Benidipine reduced parasite load and inflammatory process in cardiac and } \\
\text { skeletal muscle of chronically infected mice by probably acting as cruzipain } \\
\text { inhibitor. }\end{array}$ & {$[161,162]$} \\
\hline Clofazimine & Antibiotic & $\begin{array}{l}\text { Clofazimine reduced parasite load and inflammatory process in cardiac and } \\
\text { skeletal muscle of chronically infected mice, likely acting as cruzipain inhibitor. }\end{array}$ & {$[161,162]$} \\
\hline Clomipramine & Antidepressant & $\begin{array}{l}\text { Clomipramine reduce parasitemia and electrocardiographic changes and } \\
\text { preventing myocardial structural damage in murine infection. } \\
\text { Clomipramine improved survival by reducing the parasitic tissue load and } \\
\text { preventing progression of cardiac damage in chronically infected mice }\end{array}$ & $\begin{array}{l}{[174]} \\
{[175]}\end{array}$ \\
\hline Imatinib & Anti-cancer & Imatinib was moderately active against different strains and forms of $T$. cruzi & {$[165]$} \\
\hline Itraconazole & Antifungal & $\begin{array}{l}\text { Itraconazole led to parasitemia reduction and mortality protection of infected } \\
\text { mice. } \\
\text { Itraconazole treatment promoted significant parasitemia reduction in infected } \\
\text { dog. }\end{array}$ & $\begin{array}{l}{[146,152,157]} \\
{[167]}\end{array}$ \\
\hline Ketoconazole & Antifungal & $\begin{array}{l}\text { Ketoconazole showed anti-T. cruzi in vitro activity. } \\
\text { The drug displayed in vivo activity in infected mice. }\end{array}$ & $\begin{array}{l}{[148,149]} \\
{[147,150]}\end{array}$ \\
\hline Posaconazole & Antifungal & $\begin{array}{l}\text { Posaconazole showed potent in vitro activity and in vivo trypanocidal activity, } \\
\text { even against multiresistant } T \text {. cruzi strains. }\end{array}$ & $\begin{array}{l}{[15 \mid]} \\
{[154-156]}\end{array}$ \\
\hline Ravuconazole & Antifungal & Ravuconazole presented efficacy to control the infection in mice and dogs. & {$[116,117]$} \\
\hline $\begin{array}{l}\text { Fosravuconazole (EI224) } \\
\text { prodrug of ravuconazole }\end{array}$ & Antifungal & $\begin{array}{l}\text { EI } 224 \text { was well tolerated and effective in suppressing parasitemia with cure in } \\
\text { Y strain-infected mice. }\end{array}$ & [118] \\
\hline Tipifarnib & Anticancer & $\begin{array}{l}\text { Tipifarnib showed potent in vitro activity due to CYP5I T. cruzi inhibition. } \\
\text { Tipifarnib analog had potent suppressive activity on parasitemia in infected } \\
\text { mice. }\end{array}$ & $\begin{array}{l}{[159]} \\
{[158,160]}\end{array}$ \\
\hline
\end{tabular}

in T. cruzi infection outcome. ${ }^{172,181}$ Sequential treatment with allopurinol and BNZ was able to reduce parasitemia and attenuate tissue damage in infected mice. ${ }^{182}$ Generally, drug association allows to decrease the duration of the treatment limiting adverse effects related to time-dependent drug accumulation. $^{155}$ Table 4 shows other promising drug associations for the treatment of experimental $T$. cruzi infection. ${ }^{87,90,154,164,183-194}$

\section{Benznidazole Re-Dosing Regimens}

Current results of clinical trials have highlighted the need to reassess $\mathrm{BNZ}$ treatment regimens to achieve efficacy 
Table 4 Promising Drug Combinations in Experimental Treatment of Chagas Disease

\begin{tabular}{|c|c|c|}
\hline Combination & Outcome & References \\
\hline BNZ/VFV & Combination presented promising results on parasitic blood load and cure levels in infected mice. & [119] \\
\hline BNZ/itraconazole & $\begin{array}{l}\text { Combination improved parasitemia reduction and total survival, reduced heart } \mathrm{qPCR} \text { positivity and } \\
\text { cardiac damage in VL-I0-infected dogs. } \\
\text { Itraconazole improved plasma concentration of BNZ. } \\
\text { Combination led to an improvement in parasitemia reduction, and cardiac damage in infected mice. }\end{array}$ & $\begin{array}{l}{[176,178]} \\
{[177]} \\
{[157]}\end{array}$ \\
\hline BNZ/ketoconazole & $\begin{array}{l}\text { Combination induced a synergic effect in mice infected with } C L \text { and } Y T \text {. cruzi strains, but no differences } \\
\text { were observed in Colombian strain-infected animals. }\end{array}$ & [150] \\
\hline BNZ/fosravuconazole & $\begin{array}{l}\text { In vitro interaction was positive and in infected mice. Early treatment induced } 100 \% \text { of cure and } \\
\text { beneficial effect on well-established infection. }\end{array}$ & [118] \\
\hline BNZ/posaconazole & $\begin{array}{l}\text { Shorter duration of the treatment with combination induced cure in acutely or chronically Tulahen- } \\
\text { infected mice but did not improve the curative effect of posaconazole in Y strain infection. } \\
\text { Sequential and combined treatments were beneficial in murine infection, decreasing the time or dose of } \\
\text { the BNZ treatment. } \\
\text { Combination showed same efficacy of each drug alone in Colombian strain-infected mice and improved } \\
\text { efficacy in Brazil strain-infected mice. } \\
\text { Treatment of acute murine infection with the combination was more effective in reducing parasitemia } \\
\text { and myocardial injury, compared to monotherapies. }\end{array}$ & $\begin{array}{l}{[155]} \\
{[156]} \\
{[56]} \\
{[179]}\end{array}$ \\
\hline BNZ/voriconazole & $\begin{array}{l}\text { In vitro results indicated an additive interaction. In vivo, all treatments were well tolerated, and } \\
\text { combination elicited no additional benefits over BNZ alone. }\end{array}$ & {$[180]$} \\
\hline BNZ/arylimidamides & $\begin{array}{l}\text { Trypanocidal activity was improved by combination therapies (BNZ plus DB766, DB289 or DB1965) in } \\
\text { infected mice. }\end{array}$ & {$[87,90]$} \\
\hline BNZ/allopurinol & $\begin{array}{l}\text { Allopurinol combined with low dose of BNZ had a positive interaction on serology and pathology of } \\
\text { infected mice. } \\
\text { Sequential treatment exhibited beneficial effects on acute and chronic infection in mice. } \\
\text { Allopurinol plus NFX or BNZ showed in vitro synergic effect. The combinations increased the cure } \\
\text { rate compared to BNZ alone in murine infection. }\end{array}$ & $\begin{array}{l}{[181]} \\
{[182]} \\
{[172]}\end{array}$ \\
\hline BNZ/ascorbic acid & $\begin{array}{l}\text { Ascorbic acid combined with a low dose of BNZ improved its trypanocidal activity and attenuated the } \\
\text { toxic effects of BNZ. Combination also reduced cardiac inflammation and hepatic damage. }\end{array}$ & [188] \\
\hline BNZ/acetyl salicylic acid & Aspirin combined with lower dosages of BNZ showed better therapeutic effect in infected mice. & [193] \\
\hline BNZ/clomipramine & Clomipramine improved BNZ activity in vitro and in vivo with no cell toxicity and fewer side effects & {$[184,189]$} \\
\hline BNZ/fenofibrate & $\begin{array}{l}\text { Fenofibrate plus a low dose of BNZ attenuated cardiac dysfunction and promoted parasite clearance in } \\
\text { mice sequentially infected with two strains of different genetic backgrounds. }\end{array}$ & [185] \\
\hline BNZ/levamisole & $\begin{array}{l}\text { Monotherapies of levamisole did not decrease parasitemia nor mortality rates. In combinations with a } \\
\text { low dose of BNZ, it led to a slight improvement in the effectiveness of monotherapy }\end{array}$ & [192] \\
\hline BNZ/NFX & $\begin{array}{l}\text { Combining shorter treatments could cure mice, but the association led to the behavioral alterations of } \\
\text { treated mice. }\end{array}$ & [155] \\
\hline BNZ/simvastatin & Simvastatin improved BNZ activity in murine model of Chagas heart disease & {$[186]$} \\
\hline $\begin{array}{l}\text { BNZ/clofazimine or } \\
\text { BNZ/benidipine }\end{array}$ & $\begin{array}{l}\text { Reduced dose of } 30 \mathrm{mg} / \mathrm{kg} \text { of BNZ associated with both drugs had the same efficacy as single } 75 \mathrm{mg} / \mathrm{kg} \text { of } \\
\text { BNZ in chronic model of Chagas disease in mice with no cure. }\end{array}$ & [164] \\
\hline $\begin{array}{l}\text { Itraconazole/ } \\
\text { amiodarone }\end{array}$ & $\begin{array}{l}\text { The combination was benefic in infected dogs compared to non-treated control. } \\
\text { The combinations were more effective in vitro } T \text {. cruzi-infection than monotherapy or BNZ; without } \\
\text { affecting host cell metabolism and better preserving the integrity of infected cells. }\end{array}$ & $\begin{array}{l}{[190]} \\
{[191]}\end{array}$ \\
\hline
\end{tabular}

(Continued) 
Table 4 (Continued).

\begin{tabular}{|l|l|l|}
\hline Combination & Outcome & References \\
\hline $\begin{array}{l}\text { Posaconazole/ } \\
\text { amiodarone }\end{array}$ & $\begin{array}{l}\text { Amiodarone has direct in vitro and in vivo activity against T. cruzi and showed synergic effect with } \\
\text { posaconazole. } \\
\text { In vitro association improved IC } 50 \text { and lead alterations in the parasite. }\end{array}$ & [154] \\
\hline $\begin{array}{l}\text { Ravuconazole/ } \\
\text { amlodipine }\end{array}$ & $\begin{array}{l}\text { In vitro assays showed an additive effect for the combination. Amlodipine improved anti-T. cruzi activity } \\
\text { of ravuconazole in infected mice. }\end{array}$ & [194] \\
\hline NFX/dipyridamole & $\begin{array}{l}\text { Dipyridamole potentiated the in vitro effect of NFX and improved efficacy of low dose of NFX in } \\
\text { murine model. }\end{array}$ & [187] \\
\hline
\end{tabular}

Abbreviations: BNZ, benznidazole; NFX, nifurtimox.

and reduce the incidence of side effects in Chagas disease patients. ${ }^{195}$ In addition, considering that the treatment protocol with BNZ for experimental murine infection was defined empirically 30 years ago, ${ }^{196}$ new experimental studies are evaluating other therapeutic regimens. In this sense, intermittent treatment with BNZ was as effective as a continuous scheme in chronically infected mice. ${ }^{197}$ Similarly, low-doses of BNZ in experimental chronic stage of mice infection promoted absence of parasitism in blood, heart and colon. ${ }^{198}$ Bustamante et al proposed new once-a-week regimens of BNZ administration at 2.5 to 5 times higher than standard daily dose. This intermittent regimen rapidly eliminated actively replicating parasites and ultimately eradicated the residual, transiently dormant parasite population in mice. ${ }^{199}$

Molina and co-authors reviewed the outcomes of BNZ treatment regimens in murine infection and found that the dose, either daily or the cumulative dose, had the greatest impact on effectiveness. ${ }^{200}$ Clearly, the data showed the higher the dose or exposure to the BNZ, the greater the likelihood of cure. ${ }^{200}$ Mazzeti et al showed time and concentration-dependent trypanocidal effect of BNZ in acute murine model. Furthermore, it was demonstrated that extended treatment for 40 days led to increased levels of cure in mice infected with $\mathrm{Y}$ or Colombian strain. ${ }^{201}$ Efficacy associated with pharmacokinetic (PK/PD) studies can give support in determining the most appropriate therapeutic regimens.

\section{New Drug Delivery Systems}

The standard of care and the majority of chemotherapeutic candidates for the treatment of Trypanosoma cruzi infections are poorly water-soluble molecules and their efficacy may be limited by their biopharmaceutical profile (Figures 1-3). Thus, the design of new drug delivery systems can improve drug stability, increase dissolution and absorption rate in the gut, reduce drug efflux and increase intestinal permeability, improving drug bioavailability and biodistribution profile. $^{202}$ Nanostructured delivery systems can even circumvent multidrug resistance in some cases. In this sense, few attempts were reported concerning the use of classical formulations containing anti-T. cruzi drugs in preclinical studies. ${ }^{203,204}$ Among them, a solid dispersion and a solution containing co-solvents were used in order to improve BNZ dissolution rate as shown in Table 5.

\section{Nanotechnology-Based Formulations}

Many formulations based on the nanotechnology were tested in vivo in mice model of experimental infection with T. cruzi (Table 5). Different types of liposomes, nanoemulsions/microemulsions and self-emulsifying delivery systems were developed. Yardley and Croft tested commercially available Amphotericin B lipid nanoformulations by intravenous and oral routes in mice. ${ }^{205}$ Amphotericin $\mathrm{B}$ was active in vitro and reduced parasite burden in $T$. cruzi-infected mice (Y/Tulahuen strains). Among them, AmBisome ${ }^{\circledR}$ was the most active formulation of amphotericin $\mathrm{B}$, although no formulations cleared parasites from blood as effectively as BNZ. Cencig et al evaluated AmBisome ${ }^{\circledR}$ in Tulahuen infected mice in acute and chronic phases and observed that intraperitoneal treatment with Amphotericin B failed to cure mice from infection and to eliminate parasites. ${ }^{155,206}$ Similar results were obtained by Clemons et al. ${ }^{207}$ Taken together these studies demonstrated that amphotericin B was active against $T$. cruzi infection, but it was unable to produce cure and to eliminate parasites from tissues in pre-clinical models. 
Table 5 Drug Delivery and Nanomedicine-Based Strategies Evaluated Against Trypanosoma cruzi in Experimental Pre-Clinical Studies

\begin{tabular}{|c|c|c|c|c|}
\hline Formulation & $\begin{array}{l}\text { Drug/Active } \\
\text { Molecule }\end{array}$ & Route & Outcome & Ref. \\
\hline \multicolumn{5}{|c|}{ Classical formulations } \\
\hline Solid dispersion in poloxamer 407 & BNZ & oral & $\begin{array}{l}15-60 \mathrm{mg} / \mathrm{kg} / \text { day solid dispersion compared with classical } 50 \mathrm{mg} \\
\mathrm{mg} / \mathrm{kg} / \mathrm{day} \text {. Same efficacy in infected mice with lower side effects in } \\
\text { acute and chronic phases, and reduced hepatotoxicity in mice. }\end{array}$ & [203] \\
\hline $\begin{array}{l}\text { Solutions with co-solvents: } \mathrm{PEG}_{400} / \\
\text { water and } \\
\mathrm{CMC/water}\end{array}$ & BNZ & oral & $\begin{array}{l}20-60 \mathrm{mg} / \mathrm{kg} / \text { day solutions compared with classical BNZ doses } \\
\text { produced the same efficacy in infected mice (Tulahuen strain) }\end{array}$ & [204] \\
\hline \multicolumn{5}{|c|}{ Nanostructured lipid-based formulations } \\
\hline $\begin{array}{l}\text { Nanostructured } \\
\text { Lipid formulations }\end{array}$ & $\begin{array}{l}\text { Amphotericin } \\
\text { B }\end{array}$ & $\begin{array}{l}\text { i.v. } \\
\text { oral }\end{array}$ & $\begin{array}{l}\text { Fungizone } \AA \text { deoxycholate, AmBisome } \AA \text { liposome, Amphocil } ₫ \\
\text { colloidal dispersion, Abelcet } ₫ \text { lipid complex. AmBisome } \AA \text { was the } \\
\text { most effective formulation with the lowest host toxicity, but less } \\
\text { than BNZ and NFX. Different protocols: BALB/c mice infected } T \text {. } \\
\text { cruzi Y/Tulahuen strains BNZ or NFX (controls) cleared blood } \\
\text { trypomastigote more rapidly than amphotericin B (I week } \times 3 \\
\text { weeks). AmBisome was the most effective formulation with the } \\
\text { lowest host toxicity. }\end{array}$ & [205] \\
\hline Liposome (Ambisome®) & $\begin{array}{l}\text { Amphotericin } \\
\text { B }\end{array}$ & i.p. & $\begin{array}{l}\text { Efficacy in acute and chronic phases of mice infected with } T \text {. cruzi } \\
\text { Tulahuen strain. The formulation showed efficacy in acute and } \\
\text { chronic phases of mice infected with } T \text {. cruzi Tulahuen strain. }\end{array}$ & [206] \\
\hline $\begin{array}{l}\text { Liposome } \\
\text { (Ambisome })^{-}\end{array}$ & $\begin{array}{l}\text { Amphotericin } \\
\text { B }\end{array}$ & i.v. & $\begin{array}{l}\text { AmBisome } ₫ \text { prolonged survival, without cure. Amastigote nests } \\
\text { found in tissues of all mice treated, heart and brain in } \\
\text { histopathological analysis in acute and chronic mice models ( } Y \text { and } \\
\mathrm{CL} \text { strains). AmBisome } ₫ \text { prolonged survival without cure of } \\
\text { infection in repeated dose regimen. }\end{array}$ & [207] \\
\hline $\begin{array}{l}\text { pH-sensitive liposomes } \\
\text { (DOPE:CHEMS) }\end{array}$ & Etanidazole & i.v. & $\begin{array}{l}\text { Reduced parasitemia in infected mice with liposome formulation at } \\
\text { lower doses versus no effect of free drug. Liposome showed in vitro } \\
\text { activity against amastigote and reduced parasitemia of infected mice. }\end{array}$ & [209] \\
\hline Nanoarchaeosomes & Imiquimod & & $\begin{array}{l}\text { Infected mice (RA strain) treated with the formulation in acute } \\
\text { phase had improved survival and showed parasitemia reduction. } \\
\text { However, efficacy was lower than BNZ classical treatment with } \\
100 \mathrm{mg} / \mathrm{kg} / \text { day. }\end{array}$ & [218] \\
\hline $\begin{array}{l}\text { Self-emulsifying drug delivery } \\
\text { system (SEDDS) }\end{array}$ & BNZ & oral & $\begin{array}{l}\text { Toxicity and efficacy similar to free-BNZ. Practical and } \\
\text { personalized orally administered liquid dosage form. }\end{array}$ & [212] \\
\hline $\begin{array}{l}\text { Self-emulsifying drug delivery } \\
\text { system (SEDDS) }\end{array}$ & BNZ & oral & $\begin{array}{l}\text { Formulation was safe for mice. } \\
\text { No additional drug toxicity in infected mice (Y strain) in } 20 \text { days at } \\
\text { doses of } 100 \mathrm{mg} / \mathrm{kg} / \text { day was observed. Oral BNZ-SEDDS } \\
\text { increased BNZ AUC. }\end{array}$ & {$[210]$} \\
\hline $\begin{array}{l}\text { Self-emulsifying drug delivery } \\
\text { system (SEDDS) }\end{array}$ & Ravuconazole & oral & $\begin{array}{l}\text { SEDDS demonstrated low in vitro and in vivo toxicity and } \\
\text { improved ravuconazole activity in vitro and reduced toxicity in } \\
\text { vivo. No formulation and drug toxicity was observed in mice. }\end{array}$ & [211] \\
\hline
\end{tabular}


Table 5 (Continued).

\begin{tabular}{|c|c|c|c|c|}
\hline Formulation & $\begin{array}{l}\text { Drug/Active } \\
\text { Molecule }\end{array}$ & Route & Outcome & Ref. \\
\hline $\begin{array}{l}\text { Poly-aggregated Amphotericin B in } \\
\text { albumin microspheres }\end{array}$ & $\begin{array}{l}\text { Amphotericin } \\
\text { B }\end{array}$ & oral & $\begin{array}{l}\text { T. cruzi-infected mice (Y strain) treated for } 10 \text { days }(10-15 \mathrm{mg} / \mathrm{kg} / \\
\text { day) reduced } 75 \% \text { parasitemia and prolonged survival. Unable to } \\
\text { cure mice. }\end{array}$ & [2।7] \\
\hline $\begin{array}{l}\text { Nanospheres of polyethylene } \\
\text { glycol-polylactide }\end{array}$ & $\begin{array}{l}\text { Bis-triazole } \\
\text { D0870 }\end{array}$ & i.v. & $\begin{array}{l}\text { T. cruzi-infected mice treated for } 30 \text { days }(3 \mathrm{mg} / \mathrm{kg} / \text { day) had cure } \\
\text { rate of } 90 \% \text { for } C L \text { strain and } 60 \% \text { for } Y \text { strain in the acute phase } \\
\text { of infection }\end{array}$ & [216] \\
\hline $\begin{array}{l}\text { Nanocapsules of polyethylene } \\
\text { glycol-polylactide }\end{array}$ & $\begin{array}{l}\text { Lychnopholide } \\
\text { (LYC) } \\
\text { (sesquiterpene } \\
\text { lactone) }\end{array}$ & $\begin{array}{l}\text { i.v. } \\
\text { oral }\end{array}$ & $\begin{array}{l}\text { Formulation induced high cure levels in acute or chronic mice } \\
\text { infection, including drug resistant strains and displayed minimal } \\
\text { cardiotoxicity. } \\
\text { Potent in vivo anti-T. cruzi activity. } \\
\text { LYC-NC reduced cardiotoxicity compared with free-LYC. } \\
\text { In vivo LYC-NC effects include: cure rates of } 100 \% \text { by PCR } \\
\text { analysis in tissue; it induced cure in mice infected with Colombian } \\
\text { strain and in mice in chronic phase of infection; nanocapsules } \\
\text { increased AUC of LYC in I2-fold; high cure rates and reduced } \\
\text { inflammation in heart of mice infected by Y, CL, VLIO and } \\
\text { Colombian strains. }\end{array}$ & $\begin{array}{l}{[138-} \\
140] \\
{[144]}\end{array}$ \\
\hline $\begin{array}{l}\text { Micelles of polyoxyethylene- } \\
\text { polyoxypropylene block copolymer } \\
\text { (poloxamer 188) }\end{array}$ & Benznidazole & oral & $\begin{array}{l}\text { Acute treatment of infected mice decreased heart inflammation and } \\
\text { anti-T. cruzi specific antibodies levels. Intermittent treatments of mice } \\
\text { with chronic infection were as effective as daily treatment. Nicaragua } \\
\text { strain-infected mice (C57BL/6) treated ( } 25-75 \mathrm{mg} / \mathrm{kg} / \text { day) during the } \\
\text { chronic phase: low doses of BNZ-nanoparticles treatment ( } 25 \mathrm{mg} / \\
\mathrm{kg} / \text { day) resulted in } 40 \% \text { negative PCR in the immunosuppressed } \\
\text { mice. Continuous } 30 \text { consecutive days and intermittent regime once } \\
\text { time week during } 13 \text { weeks for } 7 \text { days showed similar reduction of } \\
\text { parasitemia compared to classical regime. }\end{array}$ & {$[197,213]$} \\
\hline $\begin{array}{l}\text { Nanoparticles of poly-epsilon- } \\
\text { caprolactone }\end{array}$ & Ursolic acid & i.v. & $\begin{array}{l}\text { In vivo anti-T. cruzi activity led to reduction of parasitemia levels } \\
\text { inT. cruzi-infected mice (C57BL/6), Y strain. Mice treated during } \\
\text { the acute phase during } 7 \text { days with ursolic acid-nanoparticles } \\
\text { showed similar reduction of parasitemia compared to BNZ. } \\
\text { Reduced hepatotoxicity for nanoparticles. }\end{array}$ & {$[2 \mid 4]$} \\
\hline $\begin{array}{l}\text { Microparticles of poly }(D, L \text {-lactide- } \\
\text { co-glycolide) }\end{array}$ & (-)-Hinokinin & s.c. & $\begin{array}{l}\text { T. cruzi infected mice (clone CLB5) treated } 20 \text { days at } 40 \mathrm{mg} / \mathrm{kg} \\
\text { with Hinokinin-nanoparticles and } 20 \mathrm{mg} / \mathrm{kg} / \text { day with free- } \\
\text { Hinokinin. Blood parasitemia was slightly reduced with Hinokinin- } \\
\text { nanoparticles by fresh blood examination. No mice cure was } \\
\text { reported. }\end{array}$ & [2।5] \\
\hline
\end{tabular}

Abbreviations: i.v, intravenous; i.p., intraperitoneal; s.c., subcutaneous; BNZ, benznidazole; NFX, nifurtimox.

BNZ lipid formulations were also developed. They failed to improve efficacy compared with classical BNZ treatment. ${ }^{208}$ Etanidazole, which is more soluble than BNZ was encapsulated in $\mathrm{pH}$-sensitive DOPE/CHEMS liposomes and showed high improvement of the activity toward amastigotes of $T$. cruzi compared with free-drug. The study demonstrated that $\mathrm{pH}$-sensitive liposomes provide a pathway to reach more efficiently the parasites in the bloodstream and in the macrophages during the acute phase of infection. ${ }^{209}$ Lipid-based nanocarriers dispersed in aqueous media showed disadvantages due to their susceptibility to oxidation and poor stability, depending on the composition.

In this sense, self-emulsifying drug delivery systems (SEDDS) are simple lipid formulations and more versatile to associate drugs for Chagas disease treatment. These 
anhydrous systems form nano or microemulsion droplets spontaneously after reaching aqueous fluids in gastrointestinal tract. They are stable under storage with good ability to dissolve drugs with poor water solubility. BNZ was loaded in SEDDS and an improvement of the extent of BNZ absorption and body exposure after oral administration were observed in mice, with an increase of $25 \%$ in bioavailability. ${ }^{210}$ No adverse effects were observed in $T$. cruzi-infected mice after 20 oral doses of BNZ at $100 \mathrm{mg} /$ $\mathrm{kg} /$ day. ${ }^{210}$ Spósito et al using the same strategy incorporated ravuconazole in SEDDS type IIIA lipid formulation. An increased activity (1.8-fold) of ravuconazole-SEDDS against intracellular amastigotes was observed in host cardiomyocyte cell line compared with free-ravuconazole, without additional drug toxicity. ${ }^{211}$ Furthermore, an increase in efficacy was achieved with $20 \mathrm{mg} / \mathrm{kg}$ ravuconazole-SEDDS in T. cruzi-infected mice ( $\mathrm{Y}$ strain) compared to free-ravuconazole in 30 day-treatment (unpublished personal results). Thus, SEDDS are promising formulations for use in neglected diseases, including Chagas disease, because of their low cost, high stability, and ease of preparation. ${ }^{212}$

\section{Polymer-Based Nanomedicines}

An interesting work associated BNZ with non-ionic surfactant (poloxamer 188), which produced micelles with mean particle size of $63 \mathrm{~nm} .{ }^{197,213}$ Treated mice had reduced inflammatory cardiomyopathy and fibrosis in a dose-dependent manner, with doses as lower as $25 \mathrm{mg} /$ $\mathrm{kg}$ /day, which resulted in $40 \%$ negative Polymerase Chain Reaction (PCR) tests in immunosuppressed mice. Thus, BNZ polymeric nanoformulations have potential to be used in experimental therapy. By contrast, polylactides, polyglycolides, polycaprolactone, and their copolymers were used to prepare polymeric nanospheres and nanocapsules (Table 5). Poly-E-caprolactone nanoparticles containing ursolic acid with sizes lower than $200 \mathrm{~nm}$ were prepared by nanoprecipitation method and exhibited no in vitro toxicity toward LLC-MK2 fibroblasts. In $T$. cruzi-infected mice (Y strain) treated during 7 days with ursolic acid-nanoparticles, the parasitemia levels were reduced similarly to BNZ classical treatment. ${ }^{214}$ The same group prepared poly( $D, L$-lactide-co-glycolide $)$ microparticles encapsulating (-)-hinokinin (HNK), which induces only a slight reduction of parasitemia peak compared with HNK-free molecule. ${ }^{215}$ The nanospheres of polyethylene glycol-block-polylactide were prepared with bis-triazole D0870 and tested in mice infected with CL and Y strains of T. cruzi. Mice were treated daily by the intravenous route with $3 \mathrm{mg} / \mathrm{kg} / \mathrm{day}$ of D0870-loaded nanospheres and a significant cure rate of $60 \%$ for $\mathrm{Y}$ and $90 \%$ CL strains in acute mice model was observed. ${ }^{216}$

Lychnopholide (LYC), a sesquiterpene lactone encapsulated in polyethylene glycol-polylactide and in poly- $\varepsilon$-caprolactone nanocapsules (LYC-NC) showed one of the most promising nanotechnological approaches investigated up to date. In acute and chronic phases of T. cruzi experimental infection with strains sensitive and resistant to BNZ, LYC$\mathrm{NC}$ administered by oral and intravenous routes showed the highest rates of cure compared with BNZ, free-LYC and other drugs tested in vivo. ${ }^{138-140,144}$ The treatment promoted complete elimination of amastigote parasites from heart tissue in mice infected with cardiomyotropic VL10 strain, using oral doses of $12 \mathrm{mg} / \mathrm{kg} /$ day during 20 days. ${ }^{138-140,144}$ Nanoencapsulation promoted in this case an outstanding improvement of pharmacokinetic properties of LYC and dramatic reduction of cardiotoxicity. ${ }^{140}$ This study attests the potential of nanotechnological approaches to the therapy of Chagas disease. Other studies have also shown the potential use of nanotechnology approaches in experimental Chagas disease. ${ }^{197,213,216-218}$

\section{Final Comments and Future Perspectives}

Chagas disease was discovered more than a hundred years ago, but current treatment is based on two old nitroheterocyclic drugs, BNZ and NFX. Knowledge about T. cruzi and the disease has expanded, but the complexity of the parasite, the pathogenesis and the immunology of the infection defy the scientific community and hinder the drug discovery process. ${ }^{200}$ Notwithstanding, target-based and mainly phenotypic screening approaches have been widely applied. Technological advances have positively influenced the development of new compounds and approaches against T. cruzi infection. In this sense, many challenges on Chagas disease drug discovery pipeline must be overcome. The natural resistance to BNZ and NFX, verified in vitro and in vivo is an intrinsic characteristic of T. cruzi strains. The parasite stocks have shown different susceptibility profiles, a factor that can trigger some treatment failures. ${ }^{196,219-221}$ The components involved in drug resistance are not yet fully understood, ${ }^{36,39,220-222}$ but may include alternative activation of enzymes by drugs, ${ }^{223}$ increased oxidative defense $^{224}$ or DNA repair pathways, ${ }^{39}$ induction of drug efflux transporters ${ }^{222}$ and glutamine metabolism. ${ }^{225}$ In 
addition, dormant forms of $T$. cruzi have been evidenced and increased drug tolerance was demonstrated. ${ }^{226}$ Thousands of compounds have been experimentally tested in vitro, however, very few achievements in terms of translation were accomplished and among them, very few produced sterile cure in mice. Additionally, we highlight the lack of predictive and harmonized models in vitro and in vivo, ${ }^{227}$ sensitive and accurate tests to determine therapeutic efficacy, mainly in chronic stage and proper determination of toxicity and pharmacokinetics of compounds.

There are no vaccines available for Chagas disease and, considering the immunological complexity and the long duration of the infection, advances in this area are still incipient. Apart from BNZ standard of care, in front of this plethora of chemical drug classes and the preclinical efficacy results discussed in this review, sesquiterpene lactone class of natural substances associated to nanocapsules seems to be the most promising chemical entities for further investigation for Chagas disease chemotherapy. Lychnopholide and goiazensolide showed outstanding efficacy against different strains of $T$. cruzi with variable sensitivity to BNZ. Additionally, fexinidazole advanced to new clinical trial with $T$. cruzi infection (FEX12-NCT03587766). Fexinidazole metabolites seem to be an encouraging approach for further clinical trials. Among new chemical entities and repositioned drugs, nitroheterocyclic compounds and CYP51 inhibitors showed potent activity against $T$. cruzi. However, a careful evaluation of toxicity and more effective regimens must be established. Additionally, associations of drugs that share or not share the same mechanism of action can lead to superior therapeutic efficacy.

\section{Acknowledgments}

This work received support from Conselho Nacional de Desenvolvimento Científico e Tecnológico (CNPq) Brazil (\#313602/2019-0, BRICS-STI\# 442351/2017-8). ALM received support from Fundação Carlos Chagas Filho de Amparo à Pesquisa do Estado do Rio de Janeiro (Faperj) - Brazil (E-26/202.367/2019).

\section{Disclosure}

The authors report no conflicts of interest for this work.

\section{References}

1. Chagas C. Nova tripanozomiaze humana: estudos sobre a morfolojia e o ciclo evolutivo do Schizotrypanum cruzi n. gen., n. sp., ajente etiolojico de nova entidade morbida do homem. Mem Inst Oswaldo Cruz. 1909;1(2):159-218. doi:10.1590/S0074-02761909000200008
2. WHO Chagas disease (American trypanosomiasis). 2020. Available from: https://www.who.int/westernpacific/healthtopics/chagas-disease. Accessed November 20, 2020

3. Lidani KCF, Andrade FA, Bavia L, et al. Chagas disease: from discovery to a worldwide health problem. Front Public Health. 2019;7:166. doi:10.3389/fpubh.2019.00166

4. Guhl F, Ramírez JD. Poverty, migration, and chagas disease. Curr Trop Med Rep. 2021. doi:10.1007/s40475-020-00225-y

5. Brener Z. Biology of Trypanosoma Cruzi. Annu Rev Microbiol. 1973;27(1):347-382. doi:10.1146/annurev.mi.27.100173.002023

6. Carlier Y, Torrico F. Congenital infection with Trypanosoma cruzi: from mechanisms of transmission to strategies for diagnosis and control. Rev Soc Bras Med Trop. 2003;36(6):767-771. doi:10.1590/S0037-86822003000600024

7. Howard JE, Rios C, Ebensperger I, Olivos P. [Congenital Chagas' disease]. Bol Chil Parasitol. 1957;12(3):42-45.

8. Wanderley DM, Aranha Camargo LM, de Carvalho ME. [Chagas' disease: registry of an acute transfusional case]. Rev Inst Med Trop Sao Paulo. 1988;30(6):437-440. doi:10.1590/s003646651988000600009

9. Dias JCP, Amato Neto V. [Prevention concerning the different alternative routes for transmission of Trypanosoma cruzi in Brazil]. Rev Soc Bras Med Trop. 2011;44(Suppl 2):68-72. doi:10.1590/s0037-86822011000800011

10. Dias JCP. Notas sobre o Trypanosoma cruzi e suas características bio-ecológicas, como agente de enfermidades transmitidas por alimentos. Rev Soc Bras Med Trop. 2006;39(4):370-375. doi:10.1590/s0037-86822006000400010

11. Pereira KS, Schmidt FL, Guaraldo AMA, Franco RMB, Dias VL, Passos LAC. Chagas' disease as a foodborne illness. J Food Prot. 2009;72(2):441-446. doi:10.4315/0362-028x-72.2.441

12. Coura JR, Viñas PA, Junqueira AC. Ecoepidemiology, short history and control of Chagas disease in the endemic countries and the new challenge for non-endemic countries. Mem Inst Oswaldo Cruz. 2014;109(7):856-862. doi:10.1590/0074-0276140236

13. Alarcón de Noya B, Díaz-Bello Z, Colmenares C, et al. Large urban outbreak of orally acquired acute chagas disease at a school in Caracas, Venezuela. J INFECT DIS. 2010;201(9):1308-1315. doi: $10.1086 / 651608$

14. da Brasil MS. Boletim Epidemiológico - Doença de Chagas aguda no Brasil: série histórica de 2000 a 2013. 2015;46(21):1-9.

15. Ríos JF, Arboleda M, Montoya AN, Alarcón EP. [Probable outbreak of oral transmission of Chagas disease in Turbo, Antioquia]. Biomedica. 2011;31(2):185-195. doi:10.1590/S012041572011000200005

16. Shikanai-Yasuda MA, Carvalho NB. Oral transmission of chagas disease. Clin Infect Dis. 2012;54(6):845-852. doi:10.1093/cid/cir956

17. Rassi A, Rassi A. Marcondes de Rezende J. American Trypanosomiasis (Chagas Disease). Infect Dis Clin North Am. 2012;26(2):275-291. doi:10.1016/j.idc.2012.03.002

18. Pérez-Molina JA, Molina I. Chagas disease. The Lancet. 2018;391(10115):82-94. doi:10.1016/S0140-6736(17)31612-4

19. Barrett MP, Burchmore RJS, Stich A, et al. The trypanosomiases. Lancet. 2003;362(9394):1469-1480. doi:10.1016/S0140-6736 (03)14694-6

20. Remme JHF, Feenstra P, Lever PR, et al.. Tropical diseases targeted for elimination: chagas disease, lymphatic filariasis, onchocerciasis, and leprosy. In: Jamison DT, Breman JG, Measham AR, et al., editors. Disease Control Priorities in Developing Countries. 2nd ed. World Bank; 2006. Available from: http://www.ncbi.nlm.nih.gov/books/NBK11745/. Accessed November 24, 2020

21. Salomao K, Figueiredo Sadok Menna-Barreto R, Lisboa de Castro S. Stairway to heaven or hell? Perspectives and limitations of chagas disease chemotherapy. CTMC. 2016;16(20):2266-2289. doi:10.2174/1568026616666160413125049 
22. Dias JC. The indeterminate form of human chronic Chagas' disease. A clinical epidemiological review. Rev Soc Bras Med Trop. 1989;22(3):147-156. doi:10.1590/s003786821989000300007

23. Salvador F, Treviño B, Sulleiro E, et al. Trypanosoma cruzi infection in a non-endemic country: epidemiological and clinical profile. Clin Microbiol Infect. 2014;20(7):706-712. doi:10.1111/ 1469-0691.12443

24. Chapadeiro E. Clinical evolution and morbi-mortality in Chagas disease. Mem Inst Oswaldo Cruz. 1999;94(Suppl 1):309-310. doi:10.1590/s0074-02761999000700058

25. Nunes MCP, Do Carmo AAL, Rocha MOC, Ribeiro AL. Mortality prediction in Chagas heart disease. Expert Rev Cardiovasc Ther. 2012;10(9):1173-1184. doi:10.1586/erc.12.111

26. Andrade SG, Stocker-Guerret S, Pimentel AS, Grimaud JA. Reversibility of cardiac fibrosis in mice chronically infected with Trypanosoma cruzi, under specific chemotherapy. Mem Inst Oswaldo Cruz. 1991;86(2):187-200. doi:10.1590/s007402761991000200008

27. Bahia MT, de Diniz LF, Mosqueira VCF. Therapeutical approaches under investigation for treatment of Chagas disease. Expert Opin Investig Drugs. 2014;23(9):1225-1237. doi:10.1517/ 13543784.2014.922952

28. Higuchi M, De Brito T, Martins Reis M, et al. Correlation between Trypanosoma cruzi parasitism and myocardial inflammatory infiltrate in human chronic chagasic myocarditis: light microscopy and immunohistochemical findings. Cardiovasc Pathol. 1993;2(2):101-106. doi:10.1016/1054-8807(93)90021-S

29. Jones EM, Colley DG, Tostes S, Lopes ER, Vnencak-Jones CL, McCurley TL. Amplification of a Trypanosoma cruzi DNA sequence from inflammatory lesions in human chagasic cardiomyopathy. Am J Trop Med Hyg. 1993;48(3):348-357. doi:10.4269/ajtmh.1993.48.348

30. Tarleton RL, Zhang L. Chagas disease etiology: autoimmunity or parasite persistence? Parasitol Today. 1999;15(3):94-99. doi:10.1016/S0169-4758(99)01398-8

31. Viotti R, Vigliano C, Lococo B, et al. Long-term cardiac outcomes of treating chronic Chagas disease with benznidazole versus no treatment: a nonrandomized trial. Ann Intern Med. 2006;144(10):724-734. doi:10.7326/0003-4819-144-10200605160-00006

32. Bock M, Gönnert R, Haberkorn A. Studies with Bay 2502 on animals. Bol Chil Parasitol. 1969;24(1):13-19.

33. Brener Z. Atividade terapêutica do 5-nitro-furaldeído - semicarbazona (nitrofurazona) em esquemas de duração prolongada na infecção experimental do camundongo pelo Trypanosoma cruzi. Revista Do Instituto De Medicina Tropical De São Paulo. 1961;3:43-49.

34. Packchanian A. Chemotherapy of experimental Chagas' disease with nitrofuran compounds. Antibiot Chemother (Northfield). 1957;7(1):13-23.

35. de Ferreira HO. Ensaio terapêutico-clínico com benzonidazol na doença de chagas. Rev Inst Med Trop São Paulo. 1976;18(5):357364.

36. Wilkinson SR, Kelly JM. Trypanocidal drugs: mechanisms, resistance and new targets. Expert Rev Mol Med. 2009;11:e31. doi:10.1017/S1462399409001252

37. Patterson S, Fairlamb AH. Current and future prospects of nitrocompounds as drugs for trypanosomiasis and leishmaniasis. CMC. 2019;26(23):4454-4475. doi:10.2174/ 0929867325666180426164352

38. Maya JD, Cassels BK, Iturriaga-Vásquez P, et al. Mode of action of natural and synthetic drugs against Trypanosoma cruzi and their interaction with the mammalian host. Comp Biochem Physiol a Mol Integr Physiol. 2007;146(4):601-620. doi:10.1016/j.cbpa.2006.03.004
39. Rajão MA, Furtado C, Alves CL, et al. Unveiling benznidazole's mechanism of action through overexpression of DNA repair proteins in Trypanosoma cruzi. Environ Mol Mutagen. 2014;55 (4):309-321. doi:10.1002/em.21839

40. FDA O of the C. FDA approves first U.S. treatment for Chagas disease. FDA. March 24, 2020. Available from: https://www.fda. gov/news-events/press-announcements/fda-approves-first-us-treat ment-chagas-disease Accessed February 5, 2021.

41. Ribeiro V, Dias N, Paiva T, et al. Current trends in the pharmacological management of Chagas disease. Int J Parasitol Drugs Drug Resist. 2020;12:7-17. doi:10.1016/j.ijpddr.2019.11.004

42. Urbina JA. Specific chemotherapy of Chagas disease: relevance, current limitations and new approaches. Acta Trop. 2010;115(12):55-68. doi:10.1016/j.actatropica.2009.10.023

43. Yun O, Lima MA, Ellman T, et al. Feasibility, drug safety, and effectiveness of etiological treatment programs for Chagas disease in Honduras, Guatemala, and Bolivia: 10-year experience of Médecins Sans Frontières. PLoS Negl Trop Dis. 2009;3(7):e488. doi:10.1371/journal.pntd.0000488

44. Molina I, Gómez I, Prat J, et al. Randomized trial of posaconazole and benznidazole for chronic Chagas' disease. $N$ Engl J Med. 2014;370(20):1899-1908. doi:10.1056/NEJMoa1313122

45. Torrico F, Gascon J, Ortiz L, et al. Treatment of adult chronic indeterminate Chagas disease with benznidazole and three E1224 dosing regimens: a proof-of-concept, randomised, placebo-controlled trial. Lancet Infect Dis. 2018;18(4):419-430. doi:10.1016/ S1473-3099(17)30538-8

46. Bahia MT, De andrade IM, Martins TAF, et al. Fexinidazole: a potential new drug candidate for chagas disease. Pollastri MP, ed. PLoS Negl Trop Dis. 2012;6(11):e1870. doi:10.1371/journal. pntd.0001870

47. Francisco AF, Jayawardhana S, Lewis MD, et al. Nitroheterocyclic drugs cure experimental Trypanosoma cruzi infections more effectively in the chronic stage than in the acute stage. Sci Rep. 2016;6(1):35351. doi:10.1038/srep35351

48. Raether W, Seidenath H. The activity of fexinidazole (HOE 239) against experimental infections with Trypanosoma cruzi, trichomonads and Entamoeba histolytica. Ann Trop Med Parasitol. 1983;77(1):13-26. doi:10.1080/00034983.1983.11811668

49. Bahia MT, Nascimento AFS, Mazzeti AL, et al. Antitrypanosomal activity of fexinidazole metabolites, potential new drug candidates for chagas disease. Antimicrob Agents Chemother. 2014;58(8):4362-4370. doi:10.1128/AAC.02754-13

50. Filardi LS, Brener Z. A nitroimidazole-thiadiazole derivative with curative action in experimental Trypanosoma cruzi infections. Ann Trop Med Parasitol. 1982;76(3):293-297. doi:10.1080/ 00034983.1982 .11687544

51. Andrade SG, Silva RC, Santiago CMG. Freitas L a. R. Therapeutic action of MK-436 (2,5-nitroimidazole) on Trypanosoma cruzi infections in mice: a parasitological, serological, histopathological, and ultrastructural study. Bull World Health Organ. 1987;65(5):625.

52. Andrade SG, Silva RC, Santiago CM. Treatment of chronic experimental Trypanosoma cruzi infections in mice with MK436, a 2-substituted 5-nitroimidazole. Bull World Health Organ. 1989;67(5):509.

53. de Castro SL, de Meirelles MN. Mechanism of action of a nitroimidazole-thiadiazole derivate upon Trypanosoma cruzi tissue culture amastigotes. Mem Inst Oswaldo Cruz. 1990;85(1):9599. doi:10.1590/s0074-02761990000100016

54. Salomão K, de Souza EM, Carvalho SA, et al. In vitro and in vivo activities of 1,3,4-thiadiazole-2-arylhydrazone derivatives of megazol against Trypanosoma cruz i. Antimicrob Agents Chemother. 2010;54(5):2023-2031. doi:10.1128/ AAC.01241-09 
55. Sánchez-Moreno M, Gómez-Contreras F, Navarro $P$, et al. Phthalazine derivatives containing imidazole rings behave as $\mathrm{Fe}$ SOD inhibitors and show remarkable anti-T. cruzi activity in immunodeficient-mouse mode of infection. $J$ Med Chem. 2012;55(22):9900-9913. doi:10.1021/jm3011004

56. Bustamante JM, Craft JM, Crowe BD, Ketchie SA, Tarleton RL. New, combined, and reduced dosing treatment protocols cure trypanosoma cruzi infection in mice. J Infect Dis. 2014;209 (1):150-162. doi:10.1093/infdis/jit420

57. Moraes CB, Giardini MA, Kim H, et al. Nitroheterocyclic compounds are more efficacious than CYP51 inhibitors against Trypanosoma cruzi: implications for Chagas disease drug discovery and development. Sci Rep. 2015;4(1):4703. doi:10.1038/ srep04703

58. Leite DI, de Fontes FV, Bastos MM, et al. New 1,2,3-triazolebased analogues of benznidazole for use against Trypanosoma cruzi infection: in vitro and in vivo evaluations. Chem Biol Drug Des. 2018;92(3):1670-1682. doi:10.1111/cbdd.13333

59. Villalta F, Dobish MC, Nde PN, et al. VNI cures acute and chronic experimental chagas disease. J Infect Dis. 2013;208 (3):504-511. doi:10.1093/infdis/jit042

60. Guedes-da-silva FH, Batista DGJ, Da Silva CF, et al. Antitrypanosomal activity of sterol $14 \alpha$-demethylase (CYP51) inhibitors VNI and VFV in the Swiss mouse models of chagas disease induced by the trypanosoma cruzi Y strain. Antimicrob Agents Chemother. 2017;61(4):e02098-16, e02098-16. doi:10.1128/AAC.02098-16

61. Guedes-da-silva FH, Batista DGJ, da Silva CF, et al. Different therapeutic outcomes of benznidazole and VNI treatments in different genders in mouse experimental models of trypanosoma cruzi infection. Antimicrob Agents Chemother. 2015;59 (12):7564-7570. doi:10.1128/AAC.01294-15

62. de Soeiro NC, de Souza EM, da Silva CF, et al. In vitro and in vivo studies of the antiparasitic activity of Sterol $14 \alpha-$ Demethylase (CYP51) Inhibitor VNI against drug-resistant strains of Trypanosoma cruzi. Antimicrob Agents Chemother. 2013;57(9):4151-4163. doi:10.1128/AAC.00070-13

63. Keenan M, Alexander PW, Diao H, et al. Design, structureactivity relationship and in vivo efficacy of piperazine analogues of fenarimol as inhibitors of Trypanosoma cruzi. Bioorg Med Chem. 2013;21(7):1756-1763. doi:10.1016/j.bmc.2013.01.050

64. Keenan M, Abbott MJ, Alexander PW, et al. Analogues of fenarimol are potent inhibitors of Trypanosoma cruzi and are efficacious in a murine model of Chagas disease. J Med Chem. 2012;55 (9):4189-4204. doi:10.1021/jm2015809

65. Doyle PS, Chen C-K, Johnston JB, et al. A nonazole CYP51 inhibitor cures Chagas' disease in a mouse model of acute infection. Antimicrob Agents Chemother. 2010;54(6):2480-2488. doi:10.1128/AAC.00281-10

66. Hoekstra WJ, Hargrove TY, Wawrzak Z, et al. Clinical Candidate VT-1161's antiparasitic effect in vitro, activity in a murine model of chagas disease, and structural characterization in complex with the target enzyme CYP51 from Trypanosoma cruzi. Antimicrob Agents Chemother. 2016;60(2):1058-1066. doi:10.1128/AAC.02287-15

67. Calvet CM, Choi JY, Thomas D, et al. 4-aminopyridyl-based lead compounds targeting CYP51 prevent spontaneous parasite relapse in a chronic model and improve cardiac pathology in an acute model of Trypanosoma cruzi infection. PLoS Negl Trop Dis. 2017;11(12):e0006132. doi:10.1371/journal.pntd.0006132

68. Papadopoulou MV, Bloomer WD, Rosenzweig HS, et al. Nitrotriazole-based compounds as antichagasic agents in a longtreatment in vivo assay. Antimicrob Agents Chemother. 2017;61 (5):e02717-16, e02717-16. doi:10.1128/AAC.02717-16

69. Papadopoulou MV, Bloomer WD, Rosenzweig HS, Wilkinson SR, Szular J, Kaiser M. Nitrotriazole-based acetamides and propanamides with broad spectrum antitrypanosomal activity. Eur J Med Chem. 2016;123:895-904. doi:10.1016/j.ejmech.2016.08.002
70. Papadopoulou MV, Bloomer WD, Rosenzweig HS, et al. Discovery of potent nitrotriazole-based antitrypanosomal agents: in vitro and in vivo evaluation. Bioorg Med Chem. 2015;23 (19):6467-6476. doi:10.1016/j.bmc.2015.08.014

71. Papadopoulou MV, Bloomer WD, Rosenzweig HS, O’Shea IP, Wilkinson SR, Kaiser M. 3-Nitrotriazole-based piperazides as potent antitrypanosomal agents. Eur J Med Chem. 2015;103:325-334. doi:10.1016/j.ejmech.2015.08.042

72. Papadopoulou MV, Bloomer WD, Rosenzweig HS, Wilkinson SR, Kaiser M. Novel nitro(triazole/imidazole)-based heteroarylamides/sulfonamides as potential antitrypanosomal agents. Eur J Med Chem. 2014;87:79-88. doi:10.1016/j.ejmech.2014.09.045

73. Papadopoulou MV, Bloomer WD, Rosenzweig HS, et al. Novel 3nitro-1H-1,2,4-triazole-based compounds as potential antiChagasic drugs: in vivo studies. Future Med Chem. 2013;5 (15):1763-1776. doi:10.4155/fmc.13.108

74. Papadopoulou MV, Bloomer WD, Rosenzweig HS, Kaiser M, Chatelain E, Ioset J-R. Novel 3-nitro-1H-1,2,4-triazole-based piperazines and 2-amino-1,3-benzothiazoles as antichagasic agents. Bioorg Med Chem. 2013;21(21):6600-6607. doi:10.1016/j.bmc.2013.08.022

75. Papadopoulou MV, Bloomer WD, Rosenzweig HS, et al. Novel 3nitro-1H-1,2,4-triazole-based amides and sulfonamides as potential antitrypanosomal agents. J Med Chem. 2012;55(11):55545565. doi:10.1021/jm300508n

76. Papadopoulou MV, Trunz BB, Bloomer WD, et al. Novel 3-nitro-1H1,2,4-triazole-based aliphatic and aromatic amines as anti-chagasic agents. J Med Chem. 2011;54(23):8214-8223. doi:10.1021/jm201215n

77. Engel JC, Doyle PS, Hsieh I, McKerrow JH. Cysteine protease inhibitors cure an experimental trypanosoma cruzi infection. $J$ Exp Med. 1998;188(4):725-734. doi:10.1084/jem.188.4.725

78. Doyle PS, Zhou YM, Engel JC, McKerrow JH. A cysteine protease inhibitor cures Chagas' disease in an immunodeficientmouse model of infection. Antimicrob Agents Chemother. 2007;51(11):3932-3939. doi:10.1128/AAC.00436-07

79. Barr SC, Warner KL, Kornreic BG, et al. A cysteine protease inhibitor protects dogs from cardiac damage during infection by Trypanosoma cruzi. Antimicrob Agents Chemother. 2005;49 (12):5160-5161. doi:10.1128/AAC.49.12.5160-5161.2005

80. Ndao M, Beaulieu C, Black WC, et al. Reversible cysteine protease inhibitors show promise for a chagas disease cure. Antimicrob Agents Chemother. 2014;58(2):1167-1178. doi:10.1128/AAC.01855-13

81. Brak K, Kerr ID, Barrett KT, et al. Nonpeptidic tetrafluorophenoxymethyl ketone cruzain inhibitors as promising new leads for Chagas disease chemotherapy. J Med Chem. 2010;53(4):17631773. doi:10.1021/jm901633v

82. de Cardoso MV, de Siqueira LRP, da Silva EB, et al. 2-Pyridyl thiazoles as novel anti-Trypanosoma cruzi agents: structural design, synthesis and pharmacological evaluation. Eur J Med Chem. 2014;86:48-59. doi:10.1016/j.ejmech.2014.08.012

83. da Silva EB, Oliveira E, DA S, et al. . Desing and synthesis of potent anti-Trypanosoma cruzi agents new thiazoles derivatives which induce apoptotic parasite death. Eur J Med Chem. 2017;130:39-50. doi:10.1016/j.ejmech.2017.02.026

84. De oliveira Filho GB, de Cardoso MVO, Espíndola JWP, et al. Structural design, synthesis and pharmacological evaluation of thiazoles against Trypanosoma cruzi. Eur J Med Chem. 2017;141:346-361. doi:10.1016/j.ejmech.2017.09.047

85. de Oliveira Filho GB, de Oliveira Cardoso MV, Espíndola JWP, et al. Structural design, synthesis and pharmacological evaluation of 4-thiazolidinones against Trypanosoma cruzi. Bioorg Med Chem. 2015;23(23):7478-7486. doi:10.1016/j.bmc.2015.10.048

86. Soeiro MNC, Werbovetz K, Boykin DW, Wilson WD, Wang MZ, Hemphill A. Novel amidines and analogues as promising agents against intracellular parasites: a systematic review. Parasitology. 2013;140(8):929-951. doi:10.1017/S0031182013000292 
87. Da Batista GJ, Batista MM, Oliveira GM, et al. Combined treatment of heterocyclic analogues and benznidazole upon Trypanosoma cruzi in vivo. Moreno SN, ed. PLoS ONE. 2011;6 (7):e22155. doi:10.1371/journal.pone.0022155

88. Da batista DGJ, Batista MM, De oliveira GM, et al. Arylimidamide DB766, a potential chemotherapeutic candidate for Chagas' disease treatment. Antimicrob Agents Chemother. 2010;54(7):2940-2952. doi:10.1128/AAC.01617-09

89. Liu Z, Wenzler T, Brun R, Zhu X, Boykin DW. Synthesis and antiparasitic activity of new bis-arylimidamides: DB766 analogs modified in the terminal groups. Eur J Med Chem. 2014;83:167173. doi:10.1016/j.ejmech.2014.06.022

90. da Silva CF, Da Batista DGJ, Oliveira GM, et al. In vitro and in vivo investigation of the efficacy of arylimidamide DB1831 and its mesylated salt form-DB1965-against Trypanosoma cruzi infection. PLoS One. 2012;7(1). doi:10.1371/journal.pone.0030356

91. da Silva CF, de Batista DGJ, de Araújo JS, et al. Phenotypic evaluation and in silico ADMET properties of novel arylimidamides in acute mouse models of Trypanosoma cruzi infection. Drug Des Devel Ther. 2017;11:1095-1105. doi:10.2147/DDDT. S120618

92. Timm BL, da Silva PB, Batista MM, et al. In vitro and in vivo biological effects of novel arylimidamide derivatives against Trypanosoma cruzi. Antimicrob Agents Chemother. 2014;58 (7):3720-3726. doi:10.1128/AAC.02353-14

93. Álvarez G, Varela J, Cruces E, et al. Identification of a new amide-containing thiazole as a drug candidate for treatment of Chagas' disease. Antimicrob Agents Chemother. 2015;59 (3):1398-1404. doi:10.1128/AAC.03814-14

94. Santos CC, Lionel JR, Peres RB, et al. In vitro, in silico, and in vivo analyses of novel aromatic amidines against Trypanosoma cruzi. Antimicrob Agents Chemother. 2018;62:2. doi:10.1128/ AAC.02205-17

95. Saccoliti F, Di Santo R, Costi R. Recent advancement in the search of innovative antiprotozoal agents targeting trypanothione metabolism. ChemMedChem. 2020;cmdc.202000325. doi: $10.1002 / \mathrm{cmdc} .202000325$

96. de Moreira TLB, Barbosa AFS, Veiga-Santos P, et al. Effect of thiazolidine LPSF SF29 on the growth and morphology of Trypanosoma cruzi. Int J Antimicrob Agents. 2013;41(2):183187. doi:10.1016/j.ijantimicag.2012.09.018

97. Olmo F, Cussó O, Marín C, et al. In vitro and in vivo identification of tetradentated polyamine complexes as highly efficient metallodrugs against Trypanosoma cruzi. Exp Parasitol. 2016;164:20-30. doi:10.1016/j.exppara.2016.02.004

98. Martín-Escolano R, Cebrián R, Maqueda $\mathrm{M}$, et al. Assessing the effectiveness of AS-48 in experimental mice models of Chagas' disease. $J$ Antimicrob Chemother. 2020;75(6):1537-1545. doi:10.1093/jac/dkaa030

99. Martín-Escolano R, Cebrián R, Martín-Escolano J, et al. Insights into Chagas treatment based on the potential of bacteriocin AS48. Int J Parasitol Drugs Drug Resist. 2019;10:1-8. doi:10.1016/ j.ijpddr.2019.03.003

100. Paixão DA, Lopes CD, Carneiro ZA, et al. In vitro anti-Trypanosoma cruzi activity of ternary copper(II) complexes and in vivo evaluation of the most promising complex. Biomed Pharmacother. 2019;109:157166. doi:10.1016/j.biopha.2018.10.057

101. Guedes PMM, Oliveira FS, Gutierrez FRS, et al. Nitric oxide donor trans-[RuCl([15]aneN)NO] as a possible therapeutic approach for Chagas' disease. Br J Pharmacol. 2010;160 (2):270-282. doi:10.1111/j.1476-5381.2009.00576.x

102. Silva JJN, Guedes PMM, Zottis A, et al. Novel ruthenium complexes as potential drugs for Chagas's disease: enzyme inhibition and in vitro/in vivo trypanocidal activity. $\mathrm{Br} J$ Pharmacol. 2010;160(2):260-269. doi:10.1111/j.14765381.2009.00524.x
103. Silva JJN, Pavanelli WR, Pereira JCM, Silva JS, Franco DW. Experimental chemotherapy against Trypanosoma cruzi infection using ruthenium nitric oxide donors. AAC. 2009;53(10):44144421. doi:10.1128/AAC.00104-09

104. Silva JJN, Osakabe AL, Pavanelli WR, Silva JS, Franco DW. In vitro and in vivo antiproliferative and trypanocidal activities of ruthenium NO donors. Br J Pharmacol. 2007;152(1):112-121. doi:10.1038/sj.bjp.0707363

105. Neitz RJ, Chen S, Supek F, et al. Lead identification to clinical candidate selection: drugs for Chagas disease. J Biomol Screen. 2015;20(1):101-111. doi:10.1177/1087057114553103

106. Hulpia F, Van Hecke K, da França Silva C, et al. Discovery of Novel 7-Aryl 7-Deazapurine 3'-deoxy-ribofuranosyl nucleosides with potent activity against Trypanosoma cruzi. J Med Chem. 2018;61(20):9287-9300. doi:10.1021/acs.jmedchem.8b00999

107. Lin C, Hulpia F, da Silva CF, et al. Discovery of Pyrrolo[2,3- $b$ ] pyridine (1,7-Dideazapurine) nucleoside analogues as anti- trypanosoma cruzi agents. J Med Chem. 2019;62(19):8847-8865. doi:10.1021/acs.jmedchem.9b01275

108. Aguirre-Alvarado C, Zaragoza-Martínez F, Rodríguez-Páez L, et al. Trypanocidal activity of the ethyl esters of N-propyl and $\mathrm{N}$-isopropyl oxamates on intracellular amastigotes of Trypanosoma cruzi acute infected mice. J Enzyme Inhib Med Chem. 2010;25(1):111-115. doi:10.3109/14756360903027741

109. Chena MA, Elizondo S, Rodríguez-Páez L, Nogueda B, Baeza I, Wong C. Trypanocidal activity of N-isopropyl oxamate on cultured epimastigotes and murine trypanosomiasis using different Trypanosoma cruzi strains. J Enzyme Inhib Med Chem. 2005;20 (2):189-197. doi:10.1080/14756360500047019

110. Wong-Baeza C, Nogueda-Torres B, Serna M, Meza-Toledo S, Baeza I, Wong C. Trypanocidal effect of the benzyl ester of N-propyl oxamate: a bi-potential prodrug for the treatment of experimental Chagas disease. BMC Pharmacol Toxicol. 2015;16:10. doi:10.1186/s40360-015-0010-4

111. Nefertiti ASG, Batista MM, Da Silva PB, et al. In vitro and in vivo studies of the trypanocidal effect of novel quinolines. Antimicrob Agents Chemother. 2017;62(2):e01936-17. doi:10.1128/AAC.01936-17

112. Vasconcelos JF, Meira CS, Silva DN, et al. Therapeutic effects of sphingosine kinase inhibitor N,N-dimethylsphingosine (DMS) in experimental chronic Chagas disease cardiomyopathy. Sci Rep. 2017;7(1):6171. doi:10.1038/s41598-017-06275-Z

113. Olmo F, Rotger C, Ramírez-Macías I, et al. Synthesis and biological evaluation of $\mathrm{N}, \mathrm{N}$ '-squaramides with high in vivo efficacy and low toxicity: toward a low-cost drug against Chagas disease. J Med Chem. 2014;57(3):987-999. doi:10.1021/jm4017015

114. Nagendar P, Gillespie JR, Herbst ZM, et al. Triazolopyrimidines and imidazopyridines: structure-activity relationships and in vivo efficacy for trypanosomiasis. ACS Med Chem Lett. 2019;10 (1):105-110. doi:10.1021/acsmedchemlett.8b00498

115. Khare S, Nagle AS, Biggart A, et al. Proteasome inhibition for treatment of leishmaniasis, Chagas disease and sleeping sickness. Nature. 2016;537(7619):229-233. doi:10.1038/nature19339

116. Diniz de LF, Caldas IS, da Guedes PM Met al. Effects of Ravuconazole treatment on parasite load and immune response in dogs experimentally infected with Trypanosoma cruzi. AAC. 2010;54(7):2979-2986. doi:10.1128/AAC.01742-09

117. Urbina JA, Payares G, Sanoja C, Lira R, Romanha AJ. In vitro and in vivo activities of ravuconazole on Trypanosoma cruzi, the causative agent of Chagas disease. Int J Antimicrob Agents. 2003;21(1):27-38. doi:10.1016/S0924-8579(02)00273-X

118. da Diniz LF, Mazzeti AL, Caldas IS, Ribeiro I, Bahia MT. Outcome of E1224-benznidazole combination treatment for infection with a multidrug-resistant trypanosoma cruzi strain in mice. Antimicrob Agents Chemother. 2018;62(6):e0401-18. doi:10.1128/AAC.00401-18 
119. Guedes-da-silva FH, Da batista GJ, Da Silva CF, et al. Successful aspects of the coadministration of Sterol $14 \alpha$-Demethylase Inhibitor VFV and benznidazole in experimental mouse models of chagas disease caused by the drug-resistant strain of Trypanosoma cruzi. ACS Infect Dis. 2019;5(3):365-371. doi:10.1021/acsinfecdis.8b00253

120. Bastos JK, Albuquerque S, Silva MLA. Evaluation of the Trypanocidal activity of lignans isolated from the leaves of zanthoxylum naranjillo. Planta Med. 1999;65(6):541-544. doi:10.1055/s-1999-14012

121. Ferreira ME, Nakayama H, de Arias AR, et al. Effects of canthin6-one alkaloids from Zanthoxylum chiloperone on Trypanosoma cruzi-infected mice. J Ethnopharmacol. 2007;109(2):258-263. doi:10.1016/j.jep.2006.07.028

122. Jimenez-Coello M, Acosta-Viana KY, Guzman-Marin E, Perez Gonzalez C, Salud Perez GM. Anti-trypanosomal activity of (8hydroxymethylen)-trieicosanyl acetate against infective forms of Trypanosoma cruzi. Pharm Biol. 2010;48(6):666-671. doi:10.3109/13880200903241853

123. Ferreira ME, Cebrián-Torrejón G, Corrales AS, et al. Zanthoxylum chiloperone leaves extract: first sustainable Chagas disease treatment. J Ethnopharmacol. 2011;133(3):986-993. doi:10.1016/j.jep.2010.11.032

124. Marín C, Ramírez-Macías I, López-Céspedes A, et al. In vitro and in vivo trypanocidal activity of flavonoids from Delphinium staphisagria against Chagas disease. J Nat Prod. 2011;74(4):744750. doi:10.1021/np1008043

125. Jiménez-Coello M, Acosta-Viana K, Pérez M, Del GuzmánMarín S. In vivo activity of (8-Hydroxymethylen)-Trieicosanyl Acetate against Trypanosoma cruzi during acute phase of the infection. Afr J Trad Compl Alt Med. 2011;8(5S). doi:10.4314/ ajtcam.v8i5S.26

126. Meira CS, Guimarães ET, Bastos TM, et al. Physalins B and F, seco-steroids isolated from Physalis angulata L., strongly inhibit proliferation, ultrastructure and infectivity of Trypanosoma cruzi. Parasitology. 2013;140(14):1811-1821. doi:10.1017/ S0031182013001297

127. Jimenez-Coello M, Acosta-Viana KY, Ortega-Pacheco A, PerezGutierrez S, In Vivo G-ME. Antiprotozoal activity of the chloroform extract from carica papaya seeds against amastigote stage of trypanosoma cruzi during indeterminate and chronic phase of infection. Evid Based Complement Alternat Med. 2014;2014:458263. doi:10.1155/2014/458263

128. Varela J, Serna E, Torres S, et al. In vivo anti-Trypanosoma cruzi activity of hydro-ethanolic extract and isolated active principles from Aristeguietia glutinosa and mechanism of action studies. Molecules. 2014;19(6):8488-8502. doi:10.3390/ molecules 19068488

129. da Rocha CQ, Queiroz EF, Meira CS, et al. Dimeric flavonoids from Arrabidaea brachypoda and assessment of their antiTrypanosoma cruzi activity. J Nat Prod. 2014;77(6):1345-1350. doi:10.1021/np401060j

130. Meira CS, Guimarães ET, Jaf DS, et al. In vitro and in vivo antiparasitic activity of Physalis angulata L. concentrated ethanolic extract against Trypanosoma cruzi. Phytomedicine. 2015;22 (11):969-974. doi:10.1016/j.phymed.2015.07.004

131. Lozano E, Strauss M, Spina R, et al. The in vivo trypanocidal effect of the diterpene 5-epi-icetexone obtained from Salvia gilliesii. Parasitol Int. 2016;65(1):23-26. doi:10.1016/j. parint.2015.08.011

132. García-Huertas P, Olmo F, Sánchez-Moreno M, Dominguez J, Chahboun R, Triana-Chávez O. Activity in vitro and in vivo against Trypanosoma cruzi of a furofuran lignan isolated from Piper jericoense. Exp Parasitol. 2018;189:34 42. doi:10.1016/j. exppara.2018.04.009
133. Tempone AG, Sartorelli P, Mady C, Fernandes F. Natural products to anti-trypanosomal drugs: an overview of new drug prototypes for American Trypanosomiasis. Cardiovasc Hematol Agents Med Chem. 2007;5(3):222-235. doi:10.2174/ 187152507781058726

134. Varela J, Cerecetto H, Slowed GM. Development of natural products for chagas disease, how to move forward?. In: Nissapatorn $\mathrm{V}$, $\mathrm{Oz}$ HS editors. . Chagas Disease - Basic Investigations and Challenges. InTech;2018. doi:10.5772/intechopen.77234

135. Llurba Montesino N, Kaiser M, Brun R, Schmidt TJ. Search for antiprotozoal activity in herbal medicinal preparations; new natural leads against neglected tropical diseases. Molecules. 2015;20 (8):14118-14138. doi:10.3390/molecules200814118

136. Mishina YV, Krishna S, Haynes RK, Meade JC. Artemisinins inhibit Trypanosoma cruzi and Trypanosoma brucei rhodesiense in vitro growth. AAC. 2007;51(5):1852-1854. doi:10.1128/AAC.01544-06

137. Chadwick M, Trewin H, Gawthrop F, Sesquiterpenoids Lactones: WC. Benefits to plants and people. Int J Mol Sci. 2013;14 (6):12780-12805. doi:10.3390/ijms140612780

138. Branquinho RT, Mosqueira VCF, de Oliveira-silva JCV, SimõesSilva MR, Saúde-Guimarães DA, de Lana M. Sesquiterpene lactone in nanostructured parenteral dosage form is efficacious in experimental Chagas disease. Antimicrob Agents Chemother. 2014;58(4):2067-2075. doi:10.1128/AAC.00617-13

139. Cgc DM, Branquinho RT, Oliveira MT, et al. Efficacy of lychnopholide polymeric nanocapsules after oral and intravenous administration in murine experimental chagas disease. Antimicrob Agents Chemother. 2016;60(9):5215-5222. doi:10.1128/AAC.00178-16

140. Branquinho RT, Roy J, Farah C, et al. Biodegradable polymeric nanocapsules prevent cardiotoxicity of anti-Trypanosomal Lychnopholide. Sci Rep. 2017;7:44998. doi:10.1038/srep44998

141. Laurella LC, Cerny N, Bivona AE, et al. Assessment of sesquiterpene lactones isolated from Mikania plants species for their potential efficacy against Trypanosoma cruzi and Leishmania sp. Schallig HDFH, ed. PLoS Negl Trop Dis. 2017;11(9):e0005929. doi:10.1371/journal.pntd.0005929

142. Alberti AS, Cerny N, Bivona A, Cazorla SI. Antitrypanosomal and antileishmanial activities. In: Sülsen VP, Martino VS editors. Sesquiterpene Lactones. Springer International Publishing; 2018:175-196. doi:10.1007/978-3-319-78274-4 8.

143. Gonçalves-Santos E, Vilas-Boas DF, Diniz LF, et al. Sesquiterpene lactone potentiates the immunomodulatory, antiparasitic and cardioprotective effects on anti-Trypanosoma cruzi specific chemotherapy. Int Immunopharmacol. 2019;77:105961. doi:10.1016/j.intimp.2019.105961

144. Branquinho RT, de Mello CGC, Oliveira MT, et al. Lychnopholide in Poly(D,L-Lactide)- Block -polyethylene glycol nanocapsules cures infection with a drug-resistant Trypanosoma cruzi strain at acute and chronic phases. Antimicrob Agents Chemother. 2020;64(4):e01937. doi:10.1128/AAC.01937-19

145. Milagre MM, Branquinho RT, Gonçalves MF, et al. Activity of the sesquiterpene lactone goyazensolide against Trypanosoma cruzi in vitro and in vivo. Parasitology. 2020;147(1):108-119. doi:10.1017/S0031182019001276

146. McCabe RE, Remington JS, Araujo FG. In vitro and in vivo effects of itraconazole against Trypanosoma cruzi. Am J Trop Med Hyg. 1986;35(2):280-284. doi:10.4269/ajtmh.1986.35.280

147. McCabe RE, Remington JS, Araujo FG. Ketoconazole promotes parasitological cure of mice infected with Trypanosoma cruzi. Trans R Soc Trop Med Hyg. 1987;81(4):613-615. doi:10.1016/ 0035-9203(87)90430-5

148. Goad LJ, Berens RL, Marr JJ, Beach DH, Holz GG. The activity of ketoconazole and other azoles against Trypanosoma cruzi: biochemistry and chemotherapeutic action in vitro. Mol Biochem Parasitol. 1989;32(2-3):179-189. doi:10.1016/01666851(89)90069-8 
149. Lazardi K, Urbina JA, de Souza W. Ultrastructural alterations induced by two ergosterol biosynthesis inhibitors, ketoconazole and terbinafine, on epimastigotes and amastigotes of Trypanosoma (Schizotrypanum) cruzi. Antimicrob Agents Chemother. 1990;34(11):2097-2105. doi:10.1128/ aac.34.11.2097

150. Araujo MSS, Martins-Filho OA, Pereira MES, Brener Z. A combination of benznidazole and ketoconazole enhances efficacy of chemotherapy of experimental Chagas' disease. $J$ Antimicrob Chemother. 2000;45(6):819-824. doi:10.1093/jac/ 45.6.819

151. Molina J. In vivo activity of the bis-triazole D0870 against drugsusceptible and drug-resistant strains of the protozoan parasite Trypanosoma cruzi. J Antimicrob Chemother. 2000;46(1):137140. doi:10.1093/jac/46.1.137

152. de Toledo O, Bahia MT, Carneiro CMet al. Chemotherapy with benznidazole and itraconazole for mice infected with different Trypanosoma cruzi clonal genotypes. Antimicrob Agents Chemother. 2003;47(1):223-230. doi:10.1128/aac.47.1.223230.2003

153. da Guedes PMM, Urbina JA, de Lana Met al. Activity of the New Triazole Derivative Albaconazole against Trypanosoma (Schizotrypanum) cruzi in Dog Hosts. AAC. 2004;48(11):42864292. doi:10.1128/AAC.48.11.4286-4292.2004

154. Benaim G, Sanders JM, Garcia-Marchán Y, et al. Amiodarone has intrinsic anti- Trypanosoma cruzi activity and acts synergistically with posaconazole ${ }^{\dagger}$. J Med Chem. 2006;49(3):892-899. doi:10.1021/jm050691f

155. Cencig S, Coltel N, Truyens C, Carlier Y. Evaluation of benznidazole treatment combined with nifurtimox, posaconazole or AmBisome ${ }^{\circledR}$ in mice infected with Trypanosoma cruzi strains. Int $J$ Antimicrob Agents. 2012;40(6):527-532. doi:10.1016/j. ijantimicag.2012.08.002

156. . de Diniz L F, Urbina JA, de Andrade IMet al. Benznidazole and posaconazole in experimental chagas disease: positive interaction in concomitant and sequential treatments. Rodrigues MM, ed. PLoS Negl Trop Dis. 2013;7(8):e2367. doi:10.1371/journal. pntd.0002367.

157. Assíria Fontes Martins T, de Figueiredo Diniz L, Mazzeti AL, et al. Benznidazole/Itraconazole combination treatment enhances anti-trypanosoma cruzi activity in experimental chagas disease. Costa FTM, ed. PLoS ONE. 2015;10(6):e0128707. doi:10.1371/ journal.pone. 0128707

158. Buckner FS, Bahia MT, Suryadevara PK, et al. Pharmacological characterization, structural studies, and in vivo activities of antichagas disease lead compounds derived from Tipifarnib. Antimicrob Agents Chemother. 2012;56(9):4914-4921. doi:10.1128/AAC.06244-11

159. Hucke O, Gelb MH, Verlinde CLMJ, Buckner FS. The protein farnesyltransferase inhibitor tipifarnib as a new lead for the development of drugs against Chagas Disease. J Med Chem. 2005;48 (17):5415-5418. doi:10.1021/jm050441z

160. Kraus JM, Tatipaka HB, McGuffin SA, et al. Second generation analogues of the cancer drug clinical candidate tipifarnib for antichagas disease drug discovery. J Med Chem. 2010;53(10):38873898. doi:10.1021/jm 9013136

161. Bellera CL, Balcazar DE, Vanrell MC, et al. Computer-guided drug repurposing: identification of trypanocidal activity of clofazimine, benidipine and saquinavir. Eur $J$ Med Chem. 2015;93:338-348. doi:10.1016/j.ejmech.2015.01.065

162. Sbaraglini ML, Bellera CL, Fraccaroli L, et al. Novel cruzipain inhibitors for the chemotherapy of chronic Chagas disease. Int $J$ Antimicrob Agents. 2016;48(1):91-95. doi:10.1016/j. ijantimicag.2016.02.018
163. Benaim G, Paniz-Mondolfi AE, Sordillo EM, Martinez-Sotillo N. Disruption of intracellular calcium homeostasis as a therapeutic target against Trypanosoma cruzi. Front Cell Infect Microbiol. 2020;10:46. doi:10.3389/fcimb.2020.00046

164. Sbaraglini ML, Bellera CL, Quarroz Braghini J, et al. Combined therapy with Benznidazole and repurposed drugs Clofazimine and Benidipine for chronic Chagas disease. Eur J Med Chem. 2019;184:111778. doi:10.1016/j.ejmech.2019.111778

165. Simões-Silva MR, De Araújo JS, Peres RB, et al. Repurposing strategies for Chagas disease therapy: the effect of imatinib and derivatives against Trypanosoma cruzi. Parasitology. 2019;146 (8):1006-1012. doi:10.1017/S0031182019000234

166. Ferreira DD, Mesquita JT, da Costa Silva TA, et al. Efficacy of sertraline against Trypanosoma cruzi: an in vitro and in silico study. J Venom Anim Toxins Incl Trop Dis. 2018;24:30. doi:10.1186/s40409-018-0165-8

167. Planer JD, Hulverson MA, Arif JA, Ranade RM, Don R, Buckner FS. Synergy testing of FDA-approved drugs identifies potent drug combinations against Trypanosoma cruzi. PLoS Negl Trop Dis. 2014;8(7):e2977. doi:10.1371/journal.pntd.0002977

168. Marr JJ, Berens RL, Nelson DJ. Antitrypanosomal effect of allopurinol: conversion in vivo to aminopyrazolopyrimidine nucleotides by Trypanosoma curzi. Science. 1978;201 (4360):1018-1020. doi:10.1126/science.356267

169. Avila J, Avila A. Trypanosoma cruzi: allopurinol in the treatment of mice with experimental acute Chagas disease. Exp Parasitol. 1981;51(2):204-208. doi:10.1016/0014-4894(81)90109-0

170. Gobbi P, Lo Presti MS, Fernández AR, et al. Allopurinol is effective to modify the evolution of Trypanosoma cruzi infection in mice. Parasitol Res. 2007;101(5):1459-1462. doi:10.1007/ s00436-007-0644-2

171. Raviolo MA, Solana ME, Novoa MM, Gualdesi MS, Alba-Soto $\mathrm{CD}$, Briñón MC. Synthesis, physicochemical properties of allopurinol derivatives and their biological activity against Trypanosoma cruzi. Eur J Med Chem. 2013;69:455-464. doi:10.1016/j.ejmech.2013.08.045

172. Mazzeti AL, de Diniz LF, Gonçalves KR, et al. Synergic effect of allopurinol in combination with nitroheterocyclic compounds against Trypanosoma cruzi. Antimicrob Agents Chemother. 2019;63(6):e2264-18. doi:10.1128/AAC.02264-18

173. da Silva MTA, Silva-Jardim I, Portapilla GB, et al. In vivo and in vitro auranofin activity against Trypanosoma cruzi: possible new uses for an old drug. Exp Parasitol. 2016;166:189-193. doi:10.1016/j.exppara.2015.05.012

174. Rivarola HW, Bustamante JM, Lo Presti S, et al. Trypanosoma cruzi: chemotherapeutic effects of clomipramine in mice infected with an isolate obtained from an endemic area. Exp Parasitol. 2005;111(2):80-86. doi:10.1016/j.exppara.2005.05.005

175. Fauro R, Lo Presti S, Bazan C, et al. Use of clomipramine as chemotherapy of the chronic phase of Chagas disease. Parasitology. 2013;140(7):917-927. doi:10.1017/ S0031182013000103

176. Cunha ELA, da Torchelsen FKVS, Cunha LM, et al. Benznidazole, itraconazole and their combination in the treatment of acute experimental chagas disease in dogs. Exp Parasitol. 2019;204:107711. doi:10.1016/j.exppara.2019.05.005

177. Moreira da Silva R, Oliveira LT, Silva Barcellos NM, de Souza J, de Lana M. Preclinical monitoring of drug association in experimental chemotherapy of chagas' disease by a new HPLC-UV method. Antimicrob Agents Chemother. 2012;56(6):3344-3348. doi:10.1128/AAC.05785-11

178. Cunha ELA, da Torchelsen FKVS, Cunha LM, et al. Benznidazole, itraconazole and their combination in the treatment of acute experimental Chagas disease in dogs. MethodsX. 2019;6:2544-2552. doi:10.1016/j.mex.2019.10.007 
179. Echeverría LE, González CI, Hernandez JCM, et al. Efficacy of the Benznidazole+Posaconazole combination therapy in parasitemia reduction: an experimental murine model of acute Chagas. Rev Soc Bras Med Trop. 2020;53:e20190477. doi:10.1590/0037-8682-0477-2019

180. Gulin JEN, Eagleson MA, López-Muñoz RA, Solana ME, Altcheh J, García-Bournissen F. In vitro and in vivo activity of voriconazole and benznidazole combination on trypanosoma cruzi infection models. Acta Trop. 2020;211:105606. doi:10.1016/j.actatropica.2020.105606

181. Rial MS, Scalise ML, López Alarcón M, et al. Experimental combination therapy using low doses of benznidazole and allopurinol in mouse models of Trypanosoma cruzi chronic infection. Parasitology. 2019;146(3):305-313. doi:10.1017/ S0031182018001567

182. Grosso NL, Alarcon ML, Bua J, Laucella SA, Riarte A, Fichera LE. Combined treatment with benznidazole and allopurinol in mice infected with a virulent Trypanosoma cruzi isolate from Nicaragua. Parasitology. 2013;140(10):1225-1233. doi:10.1017/ S0031182013000176

183. Veiga-Santos P, Barrias ES, Santos JFC, et al. Effects of amiodarone and posaconazole on the growth and ultrastructure of Trypanosoma cruzi. Int J Antimicrob Agents. 2012;40(1):61-71. doi:10.1016/j.ijantimicag.2012.03.009

184. Strauss M, Lo Presti MS, Bazán PC, et al. Clomipramine and benznidazole association for the treatment of acute experimental Trypanosoma cruzi infection. Parasitol Int. 2013;62(3):293-299. doi:10.1016/j.parint.2013.02.004

185. Cevey ÁC, Mirkin GA, Donato M, et al. Treatment with Fenofibrate plus a low dose of Benznidazole attenuates cardiac dysfunction in experimental Chagas disease. Int J Parasitol Drugs Drug Resist. 2017;7(3):378-387. doi:10.1016/j.ijpddr.2017.10.003

186. González-Herrera F, Cramer A, Pimentel P, et al. Simvastatin attenuates endothelial activation through 15-Epi-Lipoxin A4 production in murine chronic chagas cardiomyopathy. Antimicrob Agents Chemother. 2017;61(3):e02137-16, e02137-16. doi:10.1128/AAC.02137-16

187. Santeliz S, Caicedo P, Giraldo E, et al. Dipyridamole potentiated the trypanocidal effect of nifurtimox and improved the cardiac function in NMRI mice with acute chagasic myocarditis. Mem Inst Oswaldo Cruz. 2017;112(9):596-608. doi:10.1590/0074-02760160499

188. Providello MV, Carneiro ZA, Portapilla GB, et al. Benefits of ascorbic acid in association with low-dose benznidazole in treatment of chagas disease. Antimicrob Agents Chemother. 2018;62 (9):e00514-18. doi:10.1128/AAC.00514-18

189. Strauss M, Rodrigues JHS, Lo Presti MS, et al. In vitro and in vivo drug combination for the treatment of Trypanosoma cruzi infection: a multivariate approach. Exp Parasitol. 2018;189:1927. doi:10.1016/j.exppara.2018.04.016

190. Madigan R, Majoy S, Ritter K, et al. Investigation of a combination of amiodarone and itraconazole for treatment of American trypanosomiasis (Chagas disease) in dogs. J Am Vet Med Assoc. 2019;255(3):317-329. doi:10.2460/javma.255.3.317

191. Sass G, Madigan RT, Joubert L-M, et al. A combination of itraconazole and amiodarone is highly effective against trypanosoma cruzi infection of human stem cell-derived cardiomyocytes. Am J Trop Med Hyg. 2019;101(2):383-391. doi:10.4269/ajtmh.19-0023

192. Rocha Simões-Silva M, Brandão peres R, Britto C, et al. Impact of levamisole in co-administration with benznidazole on experimental Chagas disease. Parasitology. 2019;146(8):1055-1062. doi:10.1017/S0031182019000374

193. Pereira RS, Malvezi AD, Lovo-Martins MI, et al. Combination therapy using benznidazole and aspirin during the acute phase of experimental chagas disease prevents cardiovascular dysfunction and decreases typical cardiac lesions in the chronic Phase. Antimicrob Agents Chemother. 2020;64(7):e00069-20. doi:10.1128/AAC.00069-20
194. Machado YA, Bahia MT, Caldas IS, et al. Amlodipine increases the therapeutic potential of ravuconazole upon Trypanosoma cruzi Infection. Antimicrob Agents Chemother. 2020;64(8):e02497-19. doi:10.1128/AAC.02497-19

195. DNDi. The BENDITA study | DNDi. Drugs for Neglected Diseases initiative (DNDi). 2019. Accessed December 16, 2020. https://dndi.org/publications/2019/bendita-study/

196. Filardi LS, Brener Z. Susceptibility and natural resistance of Trypanosoma cruzi strains to drugs used clinically in Chagas disease. Trans R Soc Trop Med Hyg. 1987;81(5):755-759. doi:10.1016/0035-9203(87)90020-4

197. Rial MS, Arrúa EC, Natale MA, et al. Efficacy of continuous versus intermittent administration of nanoformulated benznidazole during the chronic phase of Trypanosoma cruzi Nicaragua infection in mice. J Antimicrob Chemother. 2020;75(7):19061916. doi:10.1093/jac/dkaa101

198. Perin L, da Fonseca KS, De Carvalho TV, et al. Low-dose of benznidazole promotes therapeutic cure in experimental chronic Chagas' disease with absence of parasitism in blood, heart and colon. Exp Parasitol. 2020;210:107834. doi:10.1016/j. exppara.2020.107834

199. Bustamante JM, Sanchez-Valdez F, Padilla AM, White B, Wang W, Tarleton RL. A modified drug regimen clears active and dormant trypanosomes in mouse models of Chagas disease. Sci Transl Med. 2020;12:567. doi:10.1126/scitranslmed.abb7656

200. Molina I, Perin L, Aviles AS, et al. The effect of benznidazole dose among the efficacy outcome in the murine animal model. A quantitative integration of the literature. Acta Trop. 2020;201:105218. doi:10.1016/j.actatropica.2019.105218

201. Mazzeti AL, de Diniz LF, Gonçalves KR, et al. Time and dosedependence evaluation of nitroheterocyclic drugs for improving efficacy following Trypanosoma cruzi infection: a pre-clinical study. Biochem Pharmacol. 2018;148:213-221. doi:10.1016/j. bcp.2018.01.005

202. Mosqueira VCF, Mazzeti AL, Bahia MT. Nanomedicines against Chagas disease. In: Applications of Nanobiotechnology for Neglected Tropical Diseases. Elsevier; 2021:169-189. doi:10.1016/B978-0-12-821100-7.00008-X

203. Davies C, Simonazzi A, Micheloud JF, et al. Benznidazole/ Poloxamer 407 solid dispersion as a new strategy to improve the treatment of experimental trypanosoma cruzi infection. $J$ Parasitol. 2020;106(3):323-333. doi:10.1645/19-80

204. Manarin R, Lamas MC, Bottasso E, Serra E, Revelli S, Salomón CJ. Efficacy of novel benznidazole solutions during the experimental infection with Trypanosoma cruzi. Parasitol Int. 2013;62 (1):79-81. doi:10.1016/j.parint.2012.09.001

205. Yardley V, Croft SL. In vitro and in vivo activity of amphotericin B-lipid formulations against experimental Trypanosoma cruzi infections. Am J Trop Med Hyg. 1999;61(2):193-197. doi:10.4269/ajtmh.1999.61.193

206. Cencig S, Coltel N, Truyens C, Carlier Y. Parasitic loads in tissues of mice infected with Trypanosoma cruzi and treated with AmBisome. PLoS Negl Trop Dis. 2011;5(6):e1216. doi:10.1371/journal.pntd.0001216

207. Clemons KV, Sobel RA, Martinez M, Correa-Oliveira R, Stevens DA. Lack of efficacy of liposomal Amphotericin B against acute and chronic Trypanosoma cruzi infection in mice. Am J Trop Med Hyg. 2017;97(4):1141-1146. doi:10.4269/ajtmh.16-0975

208. Morilla MJ, Montanari JA, Prieto MJ, Lopez MO, Petray PB, Romero EL. Intravenous liposomal benznidazole as trypanocidal agent: increasing drug delivery to liver is not enough. Int $J$ Pharm. 2004;278(2):311-318. doi:10.1016/j.ijpharm.2004.03.025

209. Morilla MJ, Montanari J, Frank F, et al. Etanidazole in pHsensitive liposomes: design, characterization and in vitro/in vivo anti-Trypanosoma cruzi activity. J Controlled Release. 2005;103 (3):599-607. doi:10.1016/j.jconrel.2004.12.012 
210. Oliveira LT, Mosqueira VCF, Castanheira R WO2015039199 Micro- and nanostructured pharmaceutical and veterinary compositions, containing benznidazole and derivatives thereof, which form micro- and nanostructures in the gastrointestinal tract, and biological uses thereof. Patent Scop e. 2014. Available from: https://patentscope.wipo.int/search/en/detail.jsf?docId= WO2015039199 Accessed November 26, 2020.

211. Spósito PÁF, Mazzeti Silva AL, De oliveira Faria C, et al. Ravuconazole self-emulsifying delivery system: in vitro activity against Trypanosoma cruzi amastigotes and in vivo toxicity. $I J N$. 2017;12:3785-3799. doi:10.2147/IJN.S133708

212. Mazzeti AL, Oliveira LT, Gonçalves KR, Schaun GC, Mosqueira VCF, Bahia MT. Benznidazole self-emulsifying delivery system: a novel alternative dosage form for Chagas disease treatment. Eur J Pharm Sci. 2020;145:105234. doi:10.1016/j.ejps.2020.105234

213. Esteva MI, Rial MS, Scalise ML, Fichera LE, Arrúa EC, Salomon CJ. Promising efficacy of benznidazole nanoparticles in acute Trypanosoma cruzi murine model: in-vitro and in-vivo studies. Am J Trop Med Hyg. 2016;95(2):388-393. doi:10.4269/ajtmh.150889

214. Abriata JP, Eloy JO, Riul TB, Campos PM, Baruffi MD, Marchetti JM. Poly-epsilon-caprolactone nanoparticles enhance ursolic acid in vivo efficacy against Trypanosoma cruzi infection. Mater Sci Eng C Mater Biol Appl. 2017;77:1196-1203. doi:10.1016/j.msec.2017.03.266

215. Saraiva J, Lira AAM, Esperandim VR, et al. (-)-Hinokinin-loaded poly(D,-lactide-co-glycolide) microparticles for Chagas disease. Parasitol Res. 2010;106(3):703-708. doi:10.1007/s00436-0101725-1

216. Molina J. Cure of experimental Chagas' disease by the bis-triazole DO870 incorporated into "stealth" polyethyleneglycol-polylactide nanospheres. J Antimicrob Chemother. 2001;47(1):101104. doi:10.1093/jac/47.1.101

217. Rolón M, Serrano DR, Lalatsa A, et al. Engineering oral and parenteral amorphous Amphotericin B Formulations against experimental Trypanosoma cruzi infections. Mol Pharm. 2017;14(4):1095-1106. doi:10.1021/acs.molpharmaceut.6b01034

218. Parra FL, Frank FM, Alliani BF, Romero EL, Petray PB. Imiquimod-loaded nanoarchaeosomes as a promising immunotherapy against Trypanosoma cruzi infection. Colloids Surf B Biointerfaces. $\quad 2020 ; 189: 110850 . \quad$ doi:10.1016/j. colsurfb.2020.110850

219. Campos MCO, Leon LL, Taylor MC, Kelly JM. Benznidazoleresistance in Trypanosoma cruzi: evidence that distinct mechanisms can act in concert. Mol Biochem Parasitol. 2014;193(1):1719. doi:10.1016/j.molbiopara.2014.01.002
220. Petravicius PO, Costa-Martins AG, Silva MN, et al. Mapping benznidazole resistance in trypanosomatids and exploring evolutionary histories of nitroreductases and ABCG transporter protein sequences. Acta Trop. 2019;200:105161. doi:10.1016/j. actatropica.2019.105161

221. Zingales B. Trypanosoma cruzi genetic diversity: something new for something known about Chagas disease manifestations, serodiagnosis and drug sensitivity. Acta Trop. 2018;184:38-52. doi:10.1016/j.actatropica.2017.09.017

222. Franco J, Ferreira RC, Ienne S, Zingales B. ABCG-like transporter of Trypanosoma cruzi involved in benznidazole resistance: gene polymorphisms disclose inter-strain intragenic recombination in hybrid isolates. Infect Genet Evol. 2015;31:198-208. doi:10.1016/j.meegid.2015.01.030

223. . Murta SMF, Krieger MA, Montenegro LRet al. Deletion of copies of the gene encoding old yellow enzyme (TcOYE), a NAD(P)H flavin oxidoreductase, associates with in vitro-induced benznidazole resistance in Trypanosoma cruzi. Mol Biochem Parasitol. 2006;146(2):151-162. doi:10.1016/j.molbiopara.2005.12.001.

224. Nogueira FB, Krieger MA, Nirdé P, Goldenberg S, Romanha AJ, Murta SMF. Increased expression of iron-containing superoxide dismutase-A (TcFeSOD-A) enzyme in Trypanosoma cruzi population with in vitro-induced resistance to benznidazole. Acta Trop. 2006;100(1-2):119-132. doi:10.1016/j.actatropica.2006.10.004

225. Dumoulin PC, Vollrath J, Tomko SS, Wang JX, Burleigh B. Glutamine metabolism modulates azole susceptibility in Trypanosoma cruzi amastigotes. eLife. 2020;9:e60226. doi:10.7554/eLife.60226

226. Sánchez-Valdéz FJ, Padilla A, Wang W, Orr D, Tarleton RL. Spontaneous dormancy protects Trypanosoma cruzi during extended drug exposure. Elife. 2018;7. doi:10.7554/eLife.34039

227. Romanha AJ, de Castro SL, De Soeiro M, et al. In vitro and in vivo experimental models for drug screening and development for Chagas disease. Mem Inst Oswaldo Cruz. 2010;105(2):233-238. doi:10.1590/S0074-02762010000200022

228. Vannier-Santos MA, Brunoro VG, de Nazaré C, et al.. Parasite, compartments, and molecules: trick versus treatment on chagas disease. In: editor, De Souza W. Biology of Trypanosoma Cruzi. IntechOpen; 2019. doi:10.5772/intechopen. 84472

\section{Publish your work in this journal}

The Journal of Experimental Pharmacology is an international, peerreviewed, open access journal publishing original research, reports, reviews and commentaries on all areas of laboratory and experimental pharmacology. The manuscript management system is completely online and includes a very quick and fair peer-review system. Visit http://www.dovepress.com/testimonials.php to read real quotes from published authors. 